Ankara Üniversitesi Türk İnklâp Tarihi Enstitüsü Atatürk Yolu Dergisi

Sayl: 68, Bahar 2021, s.283-314. (DOI: 10.46955/ankuayd.943731)

Makalenin geliş ve kabul tarihleri: 17.09.2020 - 06.04.2021 (Araştırma Makalesi)

\title{
TÜRK - YUNAN NÜFUS MÜBADELESİ SIRASINDA TIFË̈S
}

\author{
Semih ÇINAR*
}

\begin{abstract}
$\ddot{O} Z$
Savaş ve göç dönemlerinde yaygın olarak görülen bulaşıcı hastallklar, Türk - Yunan Nüfus Mübadelesi'nde de kendini göstermiştir. Mübadele işlerini yürütmek için Mübadele, Imar ve İskân Vekâleti adını taşlyan geniş kadrolu bir vekâlet kurulmuş, yeni kurulan Türkiye Cumhuriyeti'nin sağlı altyapısının yetersizliği nedeniyle sağlık işlerinde Kızılay'ın da yardımına başvurulmuştur. Mübadele, Imar ve İskân Vekâleti ile Kızllay arasında yapılan çalışma programı ile mübadillerin sağlık kontrolleri büyük oranda Klzılay'a devredilmiştir. Yunanistan'daki bindirme iskelelerinde ve Türkiye'deki indirme iskelelerinde mübadillerin să̆lık kontrollerini yapacak să̆lık heyetleri görevlendirilmiş, yeteri kadar doktor, hemşire ve hastabakicının bulunduğu hastane ve dispanserler açılmıştır. Mübadiller arasında görülen bulaşıcı hastalıklardan biri de henüz koruyucu bir aşının ve tedavi amaçlı kullanılan etkili bir ilacın bulunamadı̆̆ tifüs hastalı̆̆g olmuştur. Tifüs hastalığının bitler vasitaslyla bulaştı̆̆ bilindiğginden mübadillerin kişisel temizliğine ve bit kontrollerine son derece dikkat edilmiştir. İskân bölgelerine götürülmeden evvel çeşitli bölgelerdeki karantina noktalarında tutulan mübadillerin buralardaki hamamlarda yıkanmaları sağlanmış, eşyaları etüv makinesinden geçirilerek dezenfekte edilmiștir. Alınan tüm önlemlere rağmen tifüs hastalığının önüne geçilememiş, özellikle Orta Karadeniz ve İç Anadolu bölgelerinde tifüs vakalarına rastlanmıştır. Bu çalışmada, mübadele yıllarında görülen tifüs vakaları Türkiye Kızılay Derneği Arşivi ve Devlet Arşivleri Başkanlığı Cumhuriyet Arşivi belgelerinden yararlanılarak tespit edilmiş, hastalı̆̆ın tüm ülkeyi etkileyen bir salgına dönüşmemesi için alınan tedbirler incelenerek sonuçları değerlendirilmiştir.
\end{abstract}

Anahtar Kelimeler: Bulaşıcı Hastalıklar, Kızılay, Mübadele, Salgın Hastalıklar, Tifüs.

* Arş. Gör., Ege Üniversitesi, Edebiyat Fakültesi, Tarih Bölümü, semihcinar59@gmail.com, (ORCID: 0000-0002-0127-2599). 


\title{
TYPHUS DURING THE TURKISH-GREEK POPULATION EXCHANGE
}

\begin{abstract}
Infectious diseases, which are common during the war and migration periods, also appeared during the Turkish - Greek Population Exchange. To carry out exchange works, a Ministry including a large staff named as Exchange, Reconstruction and Settlement was established and, due to insufficient health infrastructure of newly established Turkish Republic, it was also required the help of Red Crescent for health affairs. In accordance with the work program between the Exchange, Reconstruction and Settlement Ministry and the Red Crescent, the health checks of the exchanges have been largely transferred to the Red Crescent. There were appointed boards for health checking of emigrants at embarking piers in Greece and unshipping piers in Turkey, and hospitals and dispensaries were opened with enough doctors and nurses. One of the infectious diseases observed between emigrants was typhus which had no protective vaccine and no effective drug used for therapeutic purposes, yet. Since typhus disease was known to be transmitted through lice, great attention was paid to personal hygiene and lice controls of the emigrants. Emigrants who were kept in quarantine points in various regions before being taken to settlement areas were washed in the baths in these areas and their items were disinfected by disinfector machine. Despite all the measures taken, typhus disease could not be prevented and typhus casesappeared especially in the Central Black Sea and Central Anatolia regions. In this study, typhus cases which were seen in the these years is identified by utilizing the documents in Turkish Red Crescent Archive and Directorate of State Archives Republican Archives, and the measures which were taken to prevent the disease from turning into an epidemic affecting the whole country is examined and results is evaluated.
\end{abstract}

Keywords: Epidemics, Infectious Diseases, Population Exchange, The Red Crescent, Typhus.

\section{Extended Abstract}

The history of infectious diseases are as old as human history. Infectious diseases, which tend to spread rapidly, cause mass deaths as well as individual deaths if necessary precautions are not taken. Especially occurred in times of war and migration periods in which personal hygiene was not paid attention - spread rapidly and became an epidemic - typhus was one of the contagious diseases. In this study, it is tried to identify the effect of the disease in the cities where the immigrants resided and the course of exchange by examining the cases of typhus seen among the refugees in Turkish - Greek Population Exchange. Measures taken to prevent typhus which becomes an epidemic and affects the whole country is emphasized, 
and the results obtained from these measures have been evaluated. The basis of the research is composed of archival documents in Turkish Red Crescent Archive and Directorate of State Archives Republican Archive. Books, articles, official publications, newspapers and journals that shed light on the period and the subject are also examined, and a wide literature review is made.

The exchange took place just after Republic of Turkey was established. The war situation that continued for more than three years in Anatolia and Eastern Thrace between 1919-1922 caused the collapse of health infrastructure and the number of health institutions such as hospitals, dispensaries and pharmacies in the occupied regions decreasing to a degree could not meet the needs. The founders of Turkish Republic, who were closely witnessed the mass migration to Turkey in the late Ottoman period, tried to take all kinds of measures required for immigrants who were experiencing the same difficulties. In order to organize the exchange, a ministry called Ministry of Exchange, Reconstruction and Settlement was established with a large staff and a budget. Concerning the sending and settling of the immigrants to Turkey, the Ministry worked closely with the Ministry of Health on health issues. The main measure taken regarding the health problems of the immigrants was to apply for the help of Red Crescent. The first three items of six-point cooperation form program between government and the Red Crescent on September 5, 1923 are those which contain measures which were taken for health problems of immigrants. There were fully equipped boards of health appointed for health checking of immigrants at embarking piers in Greece and unshipping piers in Turkey by Red Crescent, and hospitals and dispensaries were opened with enough doctors and nurses. Doctors working on behalf of the Red Crescent were assigned on the ferries in order to prevent health problems that may occur during the ferry journey. The necessary drugs for the treatment of diseases among the immigrants were distributed with no charge, and various vaccination process were made to tackle with infectious diseases by Red Crescent workers assigned in Greece and Turkey.

One of the infectious diseases that were taken measures against was typhus. At the time of the exchange, the lack of an effective drugs or a protective vaccines used in treatment of typhus made it very difficult to fight against typhus. Since typhus disease was known to be transmitted through lice, great attention was paid to personal cleaning of refugees, and lice controls were made. The majority of immigrants brought from Greece to Turkey were taken to quarantine stations and washed in the baths before they were sent to settlement areas, and the lice settled on their belongings were 
disinfected destroyed in disinfector machines. Cleaning operations carried out with disinfector machines at the quarantine points continued in residential areas, and in the regions where there is no disinfector machine, vapour boxes were used which had the same function. In some periods when typhus disease was seen in Greece, the dispatch of the exchange was suspended, and the officials in the regions where the immigrants were settled were warned and asked to take necessary measures and increase the lice control.

Despite all measures taken, typhus disease could not be prevented, and typhus cases continued in some cities in Central Black Sea and Central Anatolia regions. However, the disease was prevented from spreading to the local population or becoming an epidemic affecting the whole country. As we can infer from official publications, in 1924 when population exchange took place intensively, 919 typhus cases were seen and 110 people died. Considering the fact that a protective vaccine against typhus disease or an effective drug used for therapeutic purposes were not yet found during the exchange years, there was a highly successful fight against typhus though.

\section{Giriş}

Bulaşıcı hastalıkların geçmişi insanlık tarihi kadar eski zamanlara uzanmaktadır. Hızlı bir şekilde yayılmaya müsait olan bulaşıcı hastalıklar, bireysel ölümlere yol açtığı gibi gerekli tedbirler alınmadığı takdirde salgın haline dönüşerek kitlesel ölümlere de yol açmaktadır. Tarihsel süreçte kitlesel ölümlere yol açan bulaşıcı hastalıklardan biri de tifüs hastalığı olmuştur. Tifüs hastalığı üzerine ilk çalışmalar İtalyan doktorlar Fracastori ve Massa tarafından XVI. yüzyılda yapılmış, XVII. yüzyılda ise Almanya'da Burserus ve Wolfius tifüs hastalığ 1 üzerine çalışmalar yürütmüşlerdir. XX. yüzyılın başlarında tifüs hastalığı üzerine yapılan araştırmaların artmasıyla hastalığın bilinmezlikleri ortadan kalkmıştır. 1910 yılında, Ricketts'in çalışmaları neticesinde tifüs hastalığının insanlara bitler vasıtasıyla bulaştığı anlaşılmıştır. 1913 yılında ise Prowazek'in yaptığı araştırmalar neticesinde bitler vasıtasıyla bulaşan tifüs hastalığına sebep olan virüs bulunmuştur. Hastalığa sebep olan virüse bu iki araştırmacının anısına Rickettsia Prowazeki adı verilmiştir. ${ }^{1}$ Hastalığın yegâne sebebi olan bitler, hastalığın kişiden kişiye sirayetinin de yegâne sebebidir. Hastalık virüsünü taşıyan bir bitin insanı bir kere 1sırması bile hastalığı bulaştırmaya kâfidir. ${ }^{2}$

Lutfi Aksu, Lekeli Humma (Tifüs), Ulusal Matbaa, Ankara, 1943, s. 5-9.

2 Neşet Ömer, Bitler, Bitlerin Ahval-i Hayatiye ve Vesait-i İtlafiyesi Lekeli Tifo ve Humma-yı Racianın Bitler ile Sirayeti, Kudüs, 1332, s. 24. 
Tifüs, kış ve ilkbahar mevsimlerinde daha sık görülen bir hastalıktır. Özellikle kış aylarında insanların soba başında toplanarak birbirlerine yakın oturmaları, havanın soğuk olması nedeniyle sık sık banyo yapamamaları ve çamaşır değiştirememeleri bitlenme vakalarının ve tifüslü hasta sayılarının artmasına neden olmuştur. ${ }^{3}$ Temizlik koşullarına fazla dikkat edilmeyen bekâr odaları, yolcu hanları, kahvehaneler, köy odaları, hapishaneler ve okullar gibi mekânlar ise bitlerin kolayca yayılmasını sağlamıştır. Bu mekânlarda bulunan tifüs hastalarından diğer insanlara geçen bitler evlere kadar taşınarak aile halkının diğer bireylerine de sirayet etmiştir. ${ }^{4}$ Virüs taşıyan bir bitin insanı 1sırmasından 10-14 gün sonra ilk belirtileri gözlemlenen tifüs hastalığı, şiddetli bir titreme, 40 dereceye varan ateş, bazı durumlarda kusma ve baş ağrısı ile kendini göstermektedir. Hastalığın dördüncü gününde vücudun çeşitli bölgelerinde kırmızı lekeler görünmeye başlar. Tifüs hastalığında normal zamanlarda yüzde 15-18 civarlarında seyir eden vefat oranı, hastalığın salgına dönüştüğü dönemlerde yüzde 40-50'lere kadar yükselmektedir. ${ }^{5}$

XVI. yüzyılda İtalya'da, XVII. yüzyılda ise Almanya'da görülen tifüs hastalığı, Avrupa'daki diğer ülkelerde Otuz Yıl Savaşları sırasında görülmüş, bu tarihlerden sonra XX. yüzyılın başlarına kadar Avrupa'nın çeşitli bölgelerinde salgınlara yol açmıştır. Özellikle büyük orduların toplandığı ve kişisel temizlik kurallarına riayet edilemediği savaş dönemlerinde sıklıkla görülen tifüs hastalığı, Napolyon Savaşları, Kırım Savaşı, 1877-1878 Osmanl1-Rus Savaşı, 1897 Osmanlı-Yunanistan Savaş1, Balkan Savaşları, Birinci Dünya Savaşı ve Kurtuluş Savaşı yıllarında salgın halini almıştır. ${ }^{6}$ Tifüs hastalığının salgın haline dönüşmesine neden olan bir diğer olgu ise savaşların doğal bir sonucu olarak ortaya çıkan kitlesel göçler olmuştur. Uzun ve zorlu yolculuk sırasında beslenme, barınma ve temizlik gibi temel ihtiyaçlarını dahi karşılayamayan muhacirler, bulaşıcı hastalıklara karşı savunmasız kalmışlardır. Balkan savaşları sırasında Rumeli'den göç eden muhacirlerin birçoğu kolera ve tifüs gibi bulaşıcı hastalıklara yenik düşerek hayatlarını kaybetmiştir. ${ }^{7}$

Osmanlı Devleti'nin XIX. ve XX. yüzy1llarda girdiği birçok savaşta ve bu savaşlar sonrasında yaşanan göçlerde sıklıkla görülen tifüs, özellikle Birinci Dünya Savaşı sırasında Anadolu'nun büyük bir bölümünü etkisi

THAM (Türkiye Hilal-i Ahmer Mecmuası), V/45, 15 Şubat 1926, s. 312.

Lekeli Humma, Sihhat ve İçtimaî Muavenet Vekâleti Neşriyatı, Ankara, 1943, s. 2.

THAM, V/45, 15 Şubat 1926, s. 312-313.

THAM, V/45, 15 Şubat 1926, s. 311-312.

7 Abdülkadir Noyan, Son Harplerde Salgın Hastalıklarla Savaşlarım, Ankara Tıp Fakültesi Yay., Ankara, 2019, s. 15-17; Justin McCarthy, Ölüm ve Sürgün, Çev. Fatma Sarıkaya, Türk Tarih Kurumu Yayınları, Ankara, 2014, s. 175-176. 
altına almıştır. Sarıkamış Harekâtını yürüten Üçüncü Ordu'da baş gösteren tifüs hastalığ 1 , askerlerin hava değişimi için memleketlerine gitmeleri, Rus işgaline uğrayan şehirlerden Anadolu'nun içlerine yaşanan göçler ve ordudan firar eden askerler vasıtasıyla kısa süre içinde geniş bir sahaya yayılarak salgın halini almıştır. ${ }^{8}$ Üçüncü Ordu Kumandanı Hafız Hakkı Paşa ve Altıncı Ordu Kumandanı Mareşal von der Goltz Paşa gibi yüksek rütbeli komutanların dahi ölümüne neden olan tifüs salgını, Birinci Dünya Savaş1 boyunca bu iki ordunun yakasını bırakmamıştır. Üçüncü Ordu Sıhhiye Reisi Tevfik Sağlam'ın verdiği sayılara göre savaş süresince 19.619 tifüs vakası görülmüş, 7310 kişi hayatını kaybetmiştir. ${ }^{9}$ Altıncı Ordu'da ise savaş boyunca 4983 tifüs vakası görülmüş, 1305 kişi hayatını kaybetmiştir. ${ }^{10}$

Birinci Dünya Savaşı'ndan sonra girişilen bir diğer savaş Türk Kurtuluş Savaşı olmuş, bu yıllarda - 1919-1923 arası - görülen 3425 tifüs vakasının 552'si vefatla sonuçlanmıştır. ${ }^{11}$ XIX. ve XX. yüzyıllarda girilen birçok savaş sonrasında olduğu gibi Kurtuluş Savaşı sonrasında da Anadolu'ya kitlesel bir göç yaşanmış, Lozan Antlaşması'na ek bir sözleşmeyle kabul edilen TürkYunan Nüfus Mübadelesi ile Yunanistan'da yaşayan Türkler ile Türkiye'de yaşayan Rumlar karşılıklı göç ettirilmiştir. Mübadillerin yakalanacağı her türlü bulaşıcı hastalığın yerel halka da sirayet ederek salgın halini alabileceği bilindiğinden bulaşıcı hastalıklara karşı sıkı tedbirler alınmıştır. Salgın haline dönüşmemesi için tedbir alınan bulaşıcı hastalıklardan biri de tifüs hastalığ 1 olmuştur. Bu çalışmada, Türkiye Kızılay Derneği Arşivi ve Devlet Arşivleri Başkanlığı Cumhuriyet Arşivi'nde yer alan belgeler 1şığında mübadele yıllarında görülen tifüs vakaları tespit edilmiş, hastalığın salgın haline dönüşmemesi için alınan tedbirler incelenerek sonuçları değerlendirilmiştir.

\section{1- Mübadele Sözleşmesi ve Mübadelenin Tatbiki}

Birinci Dünya Savaşı sonrasında imzalanan Mondros Ateşkes Antlaşması'nın çeşitli maddeleri gerekçe gösterilerek Anadolu ve Doğu Trakya'daki bazı şehirlerin İtilaf Devletleri tarafından işgal edilmesi Türk

8 Süleyman Tekir, "Sarıkamış Harekâtı Sonrası Türk Ordusunda Görülen Salgın Hastalıklar ve Yaşanan Kayıplar”, Kafkas Üniversitesi Sosyal Bilimler Enstitüsü Dergisi, Ek Sayı 1, (Sonbahar 2016), s. 273-275.

9 Ahmet Başustaoğlu, Bir Nefes Sıhhat, Tevfik Sağlam'ın Yaşamı, Türkiye İş Bankası Yayınları, İstanbul, 2016, s. 285.

10 Sevilay Özer, "Birinci Dünya Savaşı'nda Osmanlı Devletinde Tifüs (Lekeli Humma) Salgını", Belleten, Cilt: LXXX, Sayı: 287, (Nisan 2016), s. 252; Savaşın sağlık hizmetlerini sekteye uğratması ve mevcut sağlık personeli ve kurumlarının çoğunun ordu hizmetine alınması nedeniyle halk arasında görülen tifüs vakalarının kaydı ordudaki gibi muntazam tutulamamış, Birinci Dünya Savaşı yıllarında tifüsün yarattı̆̆ı asıl tahribat hiçbir zaman tespit edilememiştir.

11 Aksu, a.g.e., s. 22. 
milletini yeni bir savaşın içine sürüklemiştir. Mustafa Kemal (Atatürk) Paşa önderliğinde yürütülen Kurtuluş Savaşı zaferle sonuçlandırılmış, işgal altındaki şehirler tek tek kurtarılmıştır. Savaşın nihayete ermesinden sonra sıra kalıcı bir barış tesis etmeye gelmiştir. Türkiye ile İtilaf Devletleri arasındaki savaş haline son vermek ve bu devletler arasındaki ekonomik, siyasi, askeri vb. alanlardaki sorunlara bir çözüm getirmek üzere İsviçre'nin Lozan kentinde bir konferans toplanmıştır. Lozan Konferansı'nın gündem konulardan biri de 1922 Eylülü sonrasında Yunanistan'a göç eden Rumların yarattı̆ğ mülteci krizi ve Türkiye'de kalan Rum azınlıklar olmuştur.

Yunan ordusunun Anadolu'yu işgali sırasında Batı Anadolu'da yaşayan birçok Rum silahlandırılmıştır. Silahlandırılan Rumların bir kısmı muvazzaf asker olarak Yunan ordusuna alınmış, bir kısmı da Yunan ordusunun işgali altındaki bölgelerde çetecilik faaliyetlerinde bulunmuşlardır. Çetecilik faaliyetlerine girişen Rumlar, Yunan işgali altındaki bölgelerde yaşayan Türkleri göçe zorlayarak nüfus çoğunluğunu Rumlara geçirmeye çalışmışlar, bunu sağlamak için yağma, toplu katliamlar, taciz ve tecavüz gibi birçok insanlık dişı eyleme başvurmuşlardır. ${ }^{12}$ Yunan işgali sırasında oluşan asayişsizlik ortamından yararlanarak taşkınlık olaylarına karışan Rumlar, Türk ordusunun zaferinden sonra korkuya kapılmışlar, Yunan ordusunun peşi sıra Anadolu'yu terk ederek adalara ve Yunanistan ana karasına göç etmeye başlamışlardır. ${ }^{13}$

Batı Anadolu'dan Yunanistan'a Rum göçü Yunanistan'da büyük bir mesken buhranına neden olmuş, Rum göçmenleri iskân etme konusunda sıkıntılar yaşayan Yunan hükümeti, bazı Rum aileleri Yunanistan'da ikamet eden Türklerin evlerine yerleştirmeye başlamıştır. ${ }^{14}$ Birbirlerine düşman gözüyle bakan iki millete mensup fertlerin aynı evi paylaşmak zorunda kalmaları bir takım tatsız olayların yaşanmasına neden olmuş, bazı Rum aileler evlerine yerleştirildikleri Türk aileleri kapı dışarı etmişlerdir. Türk ailelerin yanına yerleştirilen Rumların ihtiyaçlarını karşılamak da Türk ailelerine bırakılmış, bu durum Türkler üzerindeki baskıyı iyice arttırmıştır. ${ }^{15}$

Batı Anadolu Rumlarının Yunanistan'a göç etmeleri sonucunda ortaya çıkan sorunlar Lozan Konferansı'nda azınlı meselelerinin görüşüldüğ̈̈

12 Zafer Çakmak, İzmir ve Çevresinde Yunan İşgali ve Rum Mezalimi (1919-1922), Yeditepe Yayınevi. İstanbul, 2007, s. 287-288.

13 Kazım Özalp, Milli Mücadele 1919-1922, Cilt I, Türk Tarih Kurumu Yayınları, Ankara, 1998, s. 236

14 Kemal Arı, Türk Ticaret-i Bahriyesi ve Mübadele Gemileri, Deniz Ticaret Odası İzmir Şubesi Yayınları, İzmir, 2009, s. 122-123.

15 Salih Özkan, Mübadele ve Niğde’ye Yapılan İskan, Köymen Yayınevi, Konya, 2010, s. 43. 
oturumlarda ele alınmış, iki devlet arasında yapılacak karşılıklı göç ile sorunun çözülmesine karar verilmiştir. Her iki tarafin da bu çözüme olumlu yaklaşması üzerine 30 Ocak 1923 tarihinde Türkiye ile Yunanistan arasında Rum ve Türk Ahalinin Mübadelesine Dair Mukavelename imzalanmıştır. On dokuz maddeden oluşan bu sözleşme ile mübadelenin kapsamı ve kuralları tespit edilmiştir. Türk topraklarında yerleşik Rum-Ortodokslar ile Yunanistan'da yerleşik Müslümanların zorunlu mübadelesine karar verilmiş, İstanbul'da yaşayan Rumlar ile Batı Trakya'da yaşayan Türkler mübadele dişı bırakılmışlardır. Mübadiller terk ettikleri ülkenin vatandaşlığını yitirecekler, gidecekleri ülkeye ayak bastıkları andan itibaren o ülkenin vatandaşı sayılacaklardı. Her türlü taşınabilir mallarını yanlarında götürebilecekler ve bu mallardan giriş - çıkış vergisi alınmayacaktı. Mübadillerin taşınmaz mallarının bedelleri tespit edilecek ve gittikleri ülkede bu taşınmazlara eş değerde taşınmaz mal verilecekti. Mübadele işlerinin takibini sağlamak üzere karma bir mübadele komisyonu - Muhtelit Mübadele Komisyonu - kurulması kararlaştırılmıştı. Birinci Dünya Savaşı'na katılmamış tarafsız bir ülkeye mensup bir başkanın yöneteceği bu komisyonda üç tarafsız üye bulunacak, bu üyeler dönüşümlü olarak komisyona başkanlık edecekti. Tarafsız üç üyenin yanı sıra Türkiye ve Yunanistan da komisyonda dörder üye bulunduracak, on bir üyeden oluşan bu komisyonun başlica görevi mübadelenin işleyişini denetleyip, mübadillerin her türlü haklarını güvence altına almak olacaktı. Komisyon, gerekli gördügü̈ durumlarda alt komisyonlar kurma yetkisine de sahipti. ${ }^{16}$

Kitlesel göçler konusunda oldukça tecrübeli bir nesil olan Türkiye Cumhuriyeti Devleti yöneticileri, karşılaşılabilecek sorunları asgariye indirmek için mümkün olan her türlü tedbiri almaya çalışmışlardır. Balkan Savaşları sırasında göç eden göçmenlerin yarattığı kargaşa hafızalardaki tazeliğini koruduğundan mübadele ile gelecek göçmenlerin aynı duruma düşmemeleri için mübadele meselesine son derece önem verilmiştir. Mübadele sürecinin oldukça karmaşık bir süreç olacağ 1 öngörüldüğünden mübadele işleriyle uğraşacak hususi bir teşkilat kurulmasına karar verilmiştir. Manisa Milletvekili Reşad Bey ile beraber 133 milletvekili, 4 Ekim 1923 tarihinde mübadele işlerini organize edecek bir vekâlet kurulması için TBMM'ye kanun teklifinde bulunmuşlardır. Teklif, 13 Ekim 1923 tarihli toplantıda kabul edilerek Mübadele, İmar ve İskân Vekâleti kurulmuş, 20 Ekim 1923 tarihinde yapılan oylamada ise İzmir milletvekili Mustafa Necati (Uğural) Bey

16 BCA (Devlet Arşivleri Başkanlığı Cumhuriyet Arşivi), 272/12-40-40-3; Ayrıca bkz. İsmail Soysal, Türkiye'nin Siyasal Andlaşmaları I. Cilt (1920-1945), Türk Tarih Kurumu Basımevi, Ankara, 2000, s. 185-191; Lozan Barış Konferansı Tutanaklar Belgeler, Çev. Seha L. Meray, Takım I, Cilt 1, Kitap 2, Ankara Üniversitesi Basımevi, Ankara, 1969, s. 17-23. 
Mübadele, İmar ve İskân Vekili seçilmiştir. ${ }^{17}$ Mustafa Necati Bey'in 6 Mart 1924 tarihindeki istifasından sonra İzmir milletvekili Mahmut Celal (Bayar) Bey Mübadele İmar ve İskân Vekilliği görevini devralmıştır. Mahmut Celal Bey'in istifasının sonra ise 17 Temmuz 1924 tarihinde Bursa milletvekili Refet (Canitez) Bey, Mübadele İmar ve İskân Vekilli olarak seçilmiş, vekâletin lağv edildiği 11 Aralık 1924 tarihine kadar bu görevi yürütmüştür. ${ }^{18}$ Geniş bir kadro ile çalışmalarına başlayan vekâletin 1923 yılı bütçesi için 6.095.183 lira, 1924 yılı bütçesi için ise 10.022.535 lira tahsis edilmiştir. ${ }^{19}$

Mübadele, İmar ve İskân Vekâleti'nin ilk icraatlarından biri hükümetin 17 Temmuz 1923 tarihinde belirlediği 8 iskân mıntıkasını tekrar gözden geçirmek olmuş, yapılan düzenlemeler sonucunda iskân mıntıkalarının sayısı 10'a çıkarılmıştır. ${ }^{20}$ Birinci mıntıka, Sinop, Samsun, Ordu, Giresun, Trabzon, Gümüşhane, Amasya, Tokat ve Çorum vilayetlerinden; ikinci mıntıka, Edirne, Kırklareli, Tekirdağ, Gelibolu ve Çanakkale vilayetlerinden; üçüncü mıntıka, Karesi vilayetinden; dördüncü mıntıka, İzmir, Manisa, Aydın, Menteşe, Afyon ve Denizli vilayetlerinden; beşinci mıntıka, Hüdavendigar vilayetinden; altıncı mıntıka, İstanbul, Çatalca ve Zonguldak vilayetlerinden; yedinci mıntıka, İzmit, Bolu, Bilecik, Eskişehir ve Kütahya vilayetlerinden; sekizinci mıntıka, Antalya, Isparta ve Burdur vilayetlerinden; dokuzuncu mintıka, Konya, Niğde, Kayseri, Aksaray ve Kırşehir vilayetlerinden; onuncu mıntıka ise Adana, Mersin, Silifke, Kozan, Cebeli Bereket, Gazi Antep ve Maraş vilayetlerinden oluşmuştur. ${ }^{21}$

Mübadillerin iskân edilecekleri bölgeler tespit edildikten sonra iskân faaliyetleri, geçici barınma ve beslenme gibi konulara açıklık getirecek kanuni düzenlemeler yapılmıştır. 8 Kasım 1923 tarihinde Mübadele, İmar ve İskân Kanunu çıkarılmış, ${ }^{22} 25$ Kasım 1923 tarihinde İaşe Talimatnamesi, 28 Kasım 1923 tarihinde ise Misafirhaneler Talimatnamesi yayınlanmıştır. ${ }^{23}$

Yunanistan'da yaşayan Türkler, gördükleri baskının da etkisiyle daha mübadelenin resmi takvimini bile beklemeden Selanik ve Kavala gibi liman şehirlerine akın ettiklerinden mübadil nakliyatının denizyolu ile yapılmasına

\footnotetext{
17 Ercan Çelebi, Mübadele, İmar ve İskân Vekâleti (Kuruluşu, Teşkilât Yapısı ve Faaliyetleri), Hiperyayın, İstanbul, 2019, s. 59-62; Kemal Arı, Büyük Mübadele Türkiye'ye Zorunlu Göç (1923-1925), Tarih Vakfı Yurt Yayınları, İstanbul, 2000, s. 28.

18 Cahide Zengin Aghatabay, Mübadelenin Mazlum Misafirleri Mübadele ve Kamuoyu 1923-1930, Bengi Kitap Yayın, İstanbul, 2009, s. 99.

19 İskân Tarihçesi, Hamit Matbaası, İstanbul, 1932, s. 135.

20 İskân Tarihçesi, s. 17.

21 THAM, III/28, 15 Kânûn-1 evvel 1923, s. 103-104.

22 Çelebi, a.g.e., s. 91-92.

23 İskân Tarihçesi, s. 17-20.
} 
karar verilmiştir ${ }^{24}$. Taşımanın deniz yolu ile yapılması karayolu ve demiryolu gibi alternatiflerine nazaran daha pratik ve ucuz olmuştur. Mübadillerin iskân edilecekleri mıntıkaların çoğunun deniz bağlantılı yerler olması da denizyolu ulaşımını cazip kılmıştır. ${ }^{25}$

Mübadillerin denizyolu ile taşınmasına karar verildikten sonra taşıma işini yapacak şirketi belirlemek için bir ihale açılmıştır. İhaleye İtalyan, Yunan, Ermeni ve Türk vapur birlikleri katılmış, İtalyan Lloyd Triestino Firması en uygun teklifi vererek ihaleyi kazanmıştır. Ancak son derece sınırlı olan ulusal sermayenin yabancı bir şirkete gidecek olması Türk Vapurcular Birliği ve kamuoyunun büyük tepkisine yol açmış, ulusal bir dava olarak görülen mübadele işinin yabancı bir şirkete verilmesi onur kırıcı bir hareket olarak yorumlanmıştır. Bu tepkiler üzerine ihale iptal edilmiş, taşıma işi Seyr-i Sefain İdaresi ve Türk Vapurcular Birliğine verilmiştir. ${ }^{26}$ Mübadillerin Türkiye'ye sevklerinin ne surette ve hangi vasitalarla yapılacağının netleşmesinden sonra üzerinde durulan en önemli konu mübadillerin sağlıklı bir şekilde Türkiye'ye getirilmeleri olmuştur.

\section{2- Mübadillerin Sağlık Sorunları İçin Alınan Önlemler}

Mübadele, Türkiye Cumhuriyeti Devleti'nin yeni kurulduğu ve birçok sorunla ilgilenmek zorunda olduğu bir dönemde gerçekleşmiştir. Üç y1lı aşkın bir süre devam eden işgaller, Anadolu ve Doğu Trakya'nın birçok yerini harabeye çevirmiştir. Özellikle Yunan işgali altındaki bölgelerde sağlık hizmetleri çökmüş, hastane, dispanser, eczane gibi sağlık kurumları kullanılmaz hale gelmiştir. Yunan işgalinden kurtulan bölgelerdeki sağlık altyapısını tekrar oluşturmak ve halka sağlık hizmeti sunmak için hummalı bir çalışma içerisine girilmiştir. Böyle bir ortamda Türkiye'ye gelecek olan mübadillerin yakalanacağı bulaşıcı hastalıklar kısa sürede Türkiye'nin tamamını etkileyen bir salgın halini alabilirdi. Mübadiller arasında ortaya çıkacak bulaşıcı hastalıklardan mübadillerin sevk ve iskân edilecekleri mıntıkalardaki yerli halkın da etkilenmesi kaçınılmazdı. Bu durumun farkında olan hükümet, daha mübadelenin başlamasından aylar önce Kızılay'ın yardımına başvurmuştur. Hükümet ile Kızılay arasında yapılan görüşmeler sonunda Kızılay’ın mübadelede yapacağı yardımlar belirlenmiş

24 İbrahim Erdal, Mübadele, Uluslaşma Sürecinde Türkiye ve Yunanistan 1923-1925, IQ Kültür Sanat Yayıncılık, İstanbul, 2006, s. 125.

25 Aghatabay, a.g.e., s. 125.

26 Kemal Arı, "Mübadele Göçmenlerini Türkiye’ye Taşıma Sorunu ve İzmir Göçmenleri (1923-1924)", Çağdaş Türkiye Tarihi Araştırmaları Dergisi, Cilt I, Sayı 1, (1991), s. 26-27; İbrahim Erdal, "Mübadil Göçmenlerin Taşınması Meselesi ve Türk Vapurcuları İle Yapılan Nakil Sözleşmesi”, Atatürk Yolu, Cilt: 8, Sayı: 31-32, (Mayıs-Kasım 2003), s. 319-321. 
ve 5 Eylül 1923 tarihinde altı maddelik bir çalışma programı oluşturulmuştur. Bu programa göre:

1. Yunanistan'daki ihraç kapılarının her birinde tam teçhizatlı birer sağlık heyeti bulundurulacaktır.

2. Yolculuk esnasında ortaya çıkacak hastalıkların tedavileri ve yolcuların iaşeleri gemilerde bulunacak sağlık heyetleri tarafından sağlanacaktır.

3. İskân bölgesi iskelelerinin her birinde onar yataklı dispanserler açılarak sağlık heyetleri bulundurulacak, iskelelere çıkan mübadele ahalisinden hasta olanlar tedavi edilecek ve yardıma muhtaç olanlara çamaşır, fanila, çorap ve ayakkabı dağıtılacaktır.

4. Hasta, ihtiyar, çocuk ve malullerin, iskelelerden iskân bölgelerine sevkleri İngilizlerden satın alınan kamyonlarla sağlanacak, bu kamyonlardan her iskelede iki ile beş adet arasında bulundurulacak, her türlü levazım ve masrafı Hilal-i Ahmer'e [Kızılay] ait olacaktır.

5. Ahalinin geçici iskânı için Hilal-i Ahmer'in İngilizlerden aldığı çeşitli büyüklükteki çadır ve barakalardan istifade edilecektir.

6. İngilizlerden satın alınan ve Çanakkale'de bulunan barakalar istifade edilmek üzere hükümete birakılacaktır. ${ }^{27}$

Altı maddelik çalışma programının ilk üç maddesi sağlık konusunda yapılacak çalışmaları içeren maddelerdir. Mübadillerin sağlıklı bir şekilde Türkiye'ye nakillerinin Yunanistan'dan sağlıklı bir şekilde ayrılmalarına bağlı olduğu bilindiğinden mübadil sevkiyatı yapılan şehirlerin hepsine birer sağl1k heyeti gönderilmiştir. Yunanistan'a gönderilen ilk heyet, 18 Ekim 1923 tarihinde yola çıkan 27. Selanik İmdad-1 Sihhi Heyeti olmuştur. Selanik'e gönderilen bu heyeti 28. Hanya İmdad-1 Sihhi Heyeti, 29. Kandiye İmdad-1 Sihhi Heyeti, 30. Kavala İmdad-1 Sihhi Heyeti, 41. Kayalar İmdad-1 Sihhi Heyeti ve 42. Kozana İmdad-1 Sıhhi Heyeti takip etmiştir. ${ }^{28}$

Türkiye'de görev yapan imdadı sihhi heyetleri ise 26. Ayvalık İmdad-1 Sihhi Heyeti, 31. Samsun İmdad-1 S1hhi Heyeti, 33. Mersin İmdad-1 Sihhi Heyeti, 34. Tekirdağ İmdad-1 Sihhi Heyeti, 35. Bandırma İmdad-1 Sihhi Heyeti, 36. Mudanya İmdad-1 Sihhi Heyeti, 37. Tuzla İmdad-1 Sihhi Heyeti, 39. Çatalca İmdad-1 Sihhi Heyeti, 40. Erdek İmdad-1 Sihhi Heyeti, 43.

27 BCA, 30/10-123-873-3; TKDA (Türkiye Kızılay Derneği Arşivi), Kutu No: 1296, Belge No: 151; THAM, III/26, 15 Ekim 1923, s. 385.

28 Mesut Çapa, Kızılay [Hilal-i Ahmer] Cemiyeti (1914-1925), Türkiye Kızılay Derneği Yayınları, Ankara, 2010, s. 166. 
Antalya İmdad-1 Sihhi Heyeti, 44. Ulukışla İmdad-1 Sıhhi Heyeti ve 45. Niğde İmdad-1 Sihhi Heyeti olmuştur. ${ }^{29}$

Yunanistan ve Türkiye'deki imdad-1 sihhi heyetlerinin her birinde gereği kadar doktor, eczacı, hastabakıcı, idare ve ambar memuru, hademe ve çamaşırcı görevlendirilmiş, hasta ve muhtaç mübadillere yardım için kullanılacak tıbbi malzeme, erzak, eşya ve çadır gibi ihtiyaçlar Kızılay tarafindan temin edilmiştir. ${ }^{30}$ Görev yaptıkları bölgelerdeki ihtiyaç doğrultusunda hastane ve dispanserler tesis eden imdad-1 sihhi heyetleri, tedaviye muhtaç görülen mübadilleri bu hastane ve dispanserlerde tedaviye almışlardır. ${ }^{31}$

Mübadillerin, Türkiye'ye getirilecekleri tarihleri beklemeden Yunanistan'daki liman kentlerine yığılmaları, barınma ve beslenme sıkıntılarıyla karşılaşmalarına neden olmuştur. $\mathrm{Bu}$ sıkıntılara bir de mevsimin kıș başlangıcı olması eklenince mübadiller arasındaki hastalık vakalarında ciddi artışlar görülmüsstür. Hükümet ile Kızılay arasında oluşturulan çalışma programının birinci maddesinde Yunanistan'da sadece sağl1k heyeti bulundurulmasına karar verildiği halde Selanik'teki olağanüstü durum dispanser ve hastane tesisini de zorunlu kılmıştır. Selanik'te biri Alacaimaret'te diğeri ise Islahane'de olmak üzere iki dispanser kurulmuştur. Ancak mübadiller arasında görülen hastalıklardaki ciddi artış bu iki dispanserin zamanla yetersiz kalmalarına neden olmuş, 17 Kasım 1923 tarihinde Selanik'te bir de hastane açılmıştır. ${ }^{32}$ Yunanistan'da hizmet veren bir diğer Kızılay hastanesi ise Kavala'da açılan 20 yataklı hastane olmuştur. $^{33}$

Mübadillerin ilk sağlı kontrolleri Yunanistan'da görevlendirilen imdad-1 sıhhi heyetleri tarafından yapılmış, hasta olduğu tespit edilen mübadiller bindirme iskelelerindeki dispanser ve hastanelerde tedavi altına alınmışlardır. Sağlık durumları iyi olan mübadiller ise gerekli koruyucu aşıları yapıldıktan sonra vapurlara bindirilerek iskân edilecekleri bölgelere sevk edilmişlerdir. Ancak günler süren deniz yolculuğu mübadillerin sağl1k durumlarında bozulmalara yol açmıştır. Vapurların kapasitesinin çok

29 Ercan Çelebi, "Yunanistan'dan Gelen Mübadillere Sunulan Sağllk Hizmetleri: Hilâl-i Ahmer İmdat Sihhî Heyetleri ve Faaliyetleri”, Yeni Türkiye, Rumeli - Balkanlar Özel Sayısı IV, Y11 21, Sayı 69, (Mart-Haziran 2015), s. 4227-4228.

30 Hilal-i Ahmer, Akşam Nüshası, 5 Mayıs 1924.

31 Türkiye Hilal-i Ahmer Cemiyeti Merkez-i Umumisi Tarafından 1341 Senesi Hilal-i Ahmer Meclis-i Umumisine Takdim Edilen (1339-1340) İki Senelik Devreye Ait Rapor, Hilal Matbaasi, İstanbul, 1341, s. 14.

32 Çapa, a.g.e., s. 171.

33 Çapa, a.g.e., s. 167. 
üzerinde yolcu alması bütün yolculara kamara tahsis edilememesine neden olmuş, birçok yolcu güvertelerde, koridorlarda ve vapurun ambar bölümlerinde yolculuk yapmak zorunda kalmıştır. Hatta hayvanlarını da yanlarında getiren mübadillerin çoğu hayvanların yerleştirildiği ambar bölümlerinde yolculuk yapmak zorunda kalmışlardır. Bu durum çevre temizliği için gerekli hassasiyetin gösterilememesine neden olmuş, tuvalet, lavabo, su depoları gibi ortak kullanım alanlarının temizliğinin sağlanamaması yolculuk koşullarını sağlık açısından son derece elverişsiz kılmıştır. ${ }^{34}$ Mübadillerin çoğu bu gibi elverişsiz ortamlarda yolculuk yaptığından vapurların doğrudan iskân mıntıkasına gitmeleri uygun görülmemiştir. Vapurlar önce çeşitli bölgelerde belirlenen tahaffuzhanelere karantina merkezlerine- uğrayarak mübadiller tekrar sağlık kontrolünden geçirilmiş ve birkaç gün karantina altında tutulduktan sonra iskân mıntıkalarına sevk edilmişlerdir. Marmara Bölgesinde iskân edilecek mübadil kafileleri Tuzla Tahaffuzhanesi'ne, Karadeniz Bölgesinde iskân edilecekler Sinop Tahaffuzhanesi'ne, Ege ve Akdeniz Bölgelerine iskân edilecekler ise Urla Tahaffuzhanesi'ne getirilerek sağlık kontrolleri yapılmış ve bir süre karantina altında tutulmuşlardır. ${ }^{35} 27$ Ocak 1924 tarihinde Kızılay'a bir yazı gönderen Mustafa Necati Bey, bu uygulamanın hem yolculuk masraflarını arttırdığını hem de mübadillerin daha fazla sefalet çekmelerine neden olduğunu bildirmiştir. Bu tarihten sonra hareket edecek vapurlarda birer doktor görevlendirilmesini ve Yunanistan'daki heyetlerin bilgilendirilerek vapurların doktorsuz hareket etmesinin önüne geçilmesini istemiştir. ${ }^{36}$ Hükümet ile Kızılay arasında yapılan çalışma programının ikinci maddesinde yolculuk sırasında ortaya çıkabilecek sağlik problemlerinin çözümü için vapurlarda sağlık heyetleri bulundurulması kararlaştırılmıştı. Mustafa Necati Bey'in yazısından anlaşıldığı kadarıyla 1924 yılı başlarında vapurlarda doktor bulundurma uygulamasına henüz geçilmemiştir. Mustafa Necati Bey'in bu isteğinden sonra Kızılay adına çalışan 11 doktor mübadil nakliyatı yapan vapurlarda görevlendirilmiştir. ${ }^{37}$ Ancak vapurlarda doktor bulundurulmaya başlandıktan sonra da bazı vapurların önce tahaffuzhanelere uğrayıp daha sonra iskân mıntıkalarına hareket ettikleri görülmektedir. Örneğin, Bahr-1 Cedit Vapuru doktorunun 28 Ağustos 1924 tarihli raporuna göre, 21 Ağustos 1924 tarihinde 1186 mübadil ile Selanik’ten yolan çıkan

34 Mehmet Ali Gökaçtı, Nüfus Mübadelesi, Kayıp Bir Kuşağın Hikâyesi, İletişim Yayınları, İstanbul, 2010, s. 148-149; Arı, Türk Ticaret-i Bahriyesi, s. 180.

35 Kemal Arı, "Cumhuriyetin İlk Yıllarında Yaşanan Göç Olayları ve Sağlık Hizmetleri", Atatürk Dönemi Sağlık Tarihi Kongresi (1920-1938), İzmir, 2009, s. 111; Fahriye Emgili, Yunanistan'dan Mersin'e, Köklerinden Koparılmış Hayatlar, Bilge Kültür Sanat, İstanbul, 2011, s. 117.

36 TKDA, Kutu No: 88, Belge No: 106.

37 THAM, III/33, 15 Mayıs 1924, s. 291. 
Bahr-1 Cedit Vapuru, önce Tuzla Tahaffuzhanesi'ne uğramış, mübadillerin bazı aşıları tatbik edildikten sonra Tekirdağ'a götürülmüşlerdir. ${ }^{38}$

Vapurlara binmeden önceki sağlı durumları Yunanistan'da görev yapan imdad-1 sıhhi heyeti doktorları, yolculuk sirasındaki durumları ise tahaffuzhanelerde ya da vapurlarda görevli doktorlar tarafindan kontrol edilen mübadiller, iskân edilecekleri mıntıkalara getirildiklerinde buralarda görevli imdad-1 sıhhi heyetleri doktorları tarafından tekrar sağl1k kontrolünden geçirilmişlerdir. Vapurlarda görevli doktorlar, yolculuk sırasında görülen hastalık, ölüm ve doğumları bildiren sağlık raporları düzenleyerek iskân mıntıkalarındaki imdad-1 sıhhi heyetlerine teslim etmişlerdir. İskân edilecekleri mıntıkalara hasta vaziyette ulaşan mübadiller ise hemen tedavi altına alınmışlardır. ${ }^{39}$ Sağlık kontrolleri sırasında mübadillerin bulaşıcı hastalıklara yakalanmalarını önleyecek koruyucu aşılar da yapılmıştır. Yunanistan'daki imdad-1 sıhhi heyetlerince ilk aşıları yapılan mübadillere oldukları aşıları gösteren aşı belgeleri verilmiş, bu belgeler vapurlarda ve Türkiye'deki indirme iskelelerinde incelenerek eksik olan aşılar tatbik edilmiştir. ${ }^{40}$

İskân edilene kadar hiçbir hastalığı bulunmadığı halde daimi iskân bölgelerine sevk edildikten sonra sağlık durumları bozulan bazı mübadiller de olmuştur. Asırlardır yaşadıkları toprakları terk etmek zorunda kalan bu insanlar iskân edildikleri bölgelerin coğrafyasına ve iklimine alışı olmadıklarından hastalıklara karşı dirençleri çok düşmüştür. Bu yüzden mübadillerin iskân edildikleri bölgelerde de sağlık kontrollerine devam edilmiş, iskân mıntıkalarının çoğunda seyyar doktorlar görevlendirilmiştir. Konya mintıkasında 3, Samsun, Mersin, Mudanya, Tekirdağ ve Uzunköprü'de 2, İzmir, Kalikratya, Darıca, Çatalca, İstanbul, Erdek, Ayvalık, Edremit, Burhaniye, Karesi mıntıkas1, Sivas ve Edirne'de ise 1 seyyar doktor görevlendirilerek iskân edilen mübadillerin sağlık durumları kontrol edilmiş ve hasta olanlar tedavi edilmiştir. ${ }^{41}$

38 Semih Çınar, Mübadelede Tekirdăg, Hilal-i Ahmer (Kızılay) Cemiyeti’nin Mübadele Yıllarında Tekirdağ Faaliyetleri (1923-1924), Hiperyayın, İstanbul, 2021, s. 81.

39 Mehmet Çanll, "Yunanistan'daki Türklerin Anadolu'ya Nakledilmesi II", Tarih ve Toplum, Cilt 22, Say1 130, (Ekim 1994), s. 245.

40 Arı, Büyük Mübadele, s. 90.

41 Türkiye Hilal-i Ahmer Cemiyeti Merkez-i Umumisi Tarafından 1341 Senesi Hilal-i Ahmer Meclis-i Umumisine Takdim Edilen (1339-1340) İki Senelik Devreye Ait Rapor, s. 21. Bu doktorların hepsinin Kızılay adına çalışan doktorlar olmadığını belirtmekte fayda vardır. Örneğin Samsun'un bazı köylerindeki mübadillerin sağlık durumlarını kontrol etmek için 15. Kolordu Tabibi Yüzbaşı Rauf Bey ve Samsun Belediye doktorlarından Osman Senai Bey görevlendirilmiştir. Bkz. BCA, 272/79-72-3-33; Benzer şekilde Trakya mıntıkasında görevlendirilen 2 seyyar doktor da Mübadele, İmar ve İskân 


\section{3- Mübadiller Arasında Görülen Tifüs Vakaları}

Mübadele sürecinde, tifüs hastalığının bir salgın haline dönüşmemesi için büyük çabalar sarf edilmiştir. Mübadele yıllarına kadar dizanteri, çiçek, tifo, veba ve sıtma gibi birçok bulaşıcı hastalığın koruyucu aşısı, serumu ve ilacı bulunup, tatbiki yaygınlaştığı halde tifüs hastalığının tedavisinde kullanılan etkili bir ilaç ya da koruyucu bir aşı henüz bulunamamıştı. ${ }^{42}$ Birinci Dünya Savaşı yıllarında Anadolu'da görülen tifüs salgını Türk doktorları aşı arayışına sevk etmiş, Üçüncü Ordu Sıhhiye Reisi Tevfik Salim (Sağlam) Bey tarafindan ilk tifüs aşısı üretilmişti. Hastalığın yüksek evresinde bulunan bir tifüslüden alınan kan, $55^{\circ} \mathrm{C}-60^{\circ} \mathrm{C}$ arası bir 1 sida 15 dakika tutularak tifüs mikrobunun kandaki etkisi kaybettiriliyor, mikroptan arındırılan kan hastalığı geçirmemiş kişilere enjekte ediliyordu. Böylece tifüs hastalığı geçirmemiş kişilerin tifüse karşı bağışıklık kazanmaları amaçlanıyordu. 1915 yılı Mart ayında hazırlanan ilk aşılar beşi doktor, dördü subay olmak üzere dokuz kişi üzerinde tecrübe edilmiştir. Aşılananların beşi tifüs hastalığına yakalanmazken dördü 15 gün içerisinde tifüse yakalanmışlardır. Ancak aşı tatbik edilen bu kişilerin hastalığg daha hafif geçirmeleri aşının başarısı olarak görülmüş, daha etkili bir aşı olmadığından aşının tatbikine devam edilmiştir. ${ }^{43}$ Tevfik Salim Bey'in ürettiği tifüs aşısı sayesinde birçok kişi tifüs hastalığına yakalanmaktan kurtulmuş ya da hastalığı daha hafif geçirmiştir. Aşıyı hazırlayabilmek için tifüslü bir hastaya ihtiyaç duyulması ise aşının en büyük eksiği olmuştur. Bu durum hastalıkları önlemek için üretilen ve depolanabilen ilaçlar olan aşıların mantığına ters düştüğünden Birinci Dünya Savaşı yıllarında bir dönem Almanya'da dahi kullanılan bu aşısının kullanımına Milli Mücadele yıllarının hemen ardından son verilmiştir. ${ }^{44}$

Tıbbi bir ilacın henüz bulunmadığı bu yıllarda tifüse karşı alınabilecek en büyük önlem bitlerden uzak durarak tifüse yakalanmamak olmuştur. $\mathrm{Bu}$ yüzden mübadillerin temizliğine ve bitlenmemelerine çok dikkat edilmiş, Yunanistan'dan Türkiye'ye taşınan mübadillerin büyük bir kısmı önce tahaffuzhane adı verilen karantina noktalarına getirilmişlerdir. Tahaffuzhanelerde görevli doktorlar tarafindan muayene edilen mübadillerin bit kontrolleri yapılmış ve buradaki hamamlarda yıkanmaları sağlanmıştır. Mübadillerin eşyaları ise tahaffuzhanelerde bulunan etüv makinelerinden

Vekâleti tarafından görevlendirilmiş, ihtiyaç duydukları tıbbi malzemeler Tekirdağ İmdad1 Sıhhi Heyeti tarafindan sağlanmıştır. Bkz. Çınar, a.g.e., s. 87-88.

42 THAM, V/45, 15 Subat 1926, s. 314.

43 Başustaoğlu, a.g.e., s. 275-277.

44 Sağlık Hizmetlerinde 50 Yıl, Sağlık ve Sosyal Yardım Bakanlığı Yayınları, Ankara, 1973, s. 99; THAM, V/45, 15 Şubat 1926, s. 314. 
geçirilmiştir. Yüksek 1sının öldürücü etkisinden yararlanmak için tasarlanan etüv makineleri eşyalar üzerindeki mikropları öldürerek dezenfekte olmalarını sağlıyordu. İki tarafı kapaklı silindir şeklinde bir kazandan oluşan etüv makinesinin içinde eşyaların konulacağı raflar bulunuyordu. Kirli tarafındaki kapaktan kazanın içindeki raflara konulan eşyalar su buharının da yardımıyla 20 dakika $110^{\circ} \mathrm{C}$ ssıda bekletilerek diğer kapaktan temiz olarak çıkarılıyordu. ${ }^{45}$ Etüv makinesi ile yapılan temizlik işlemi sonunda $40^{\circ} \mathrm{C}$ 'nin üstündeki 1sıya dayanıksız olan bitler etkisiz hale getiriliyordu. ${ }^{46}$ Eşya dezenfeksiyonu için kapalı bir mekânda sabit olarak bulunan etüv makinelerinden başka seyyar etüv makineleri ve buğu sandıkları da kullanılıyordu. Etüv makinesi ile aynı sistemde çalışan seyyar etüv makinesi bir araba üzerinde bulunuyor, yük hayvanları ile çekilerek ihtiyaç duyulan noktalara götürülebiliyordu. Etüv makinesi bulunmayan yerlerde ise etüv makinesi ile aynı görevi gören buğu sandıkları kullanılıyordu. Buğu sandığı 1915 y1lında Üçüncü Ordu Sivas Menzil Mıntıka Sertabibi Dr. Ahmet Fikri Bey tarafından bulunmuştu. İçinde eşyaları koymak için raflar bulunan iki metre boyunda, bir metre eninde ve bir metre yüksekliğindeki bir sandık bir kazanın üstüne oturtuluyor, sandığın alt kısmına kazanın ağzından daha küçük bir delik açılarak etrafı çamurla sıvanıyordu. İçi su dolu kazan 1sıtılarak suyun buharlaşması sağlanıyor, sandığın içine dolan sıcak su buharı eşyalar üzerindeki bitleri öldürüyordu. ${ }^{47}$ Bulaşıcı hastalıklarla mücadelede etkili bir araç olan etüv makinelerinin kullanımı sadece tahaffuzhanelerle sınırlı değildi. 1920'li yıllara gelindiğinde Türkiye'nin birçok şehrinde etüv makinesi bulunuyordu. Mübadelenin gerçekleştiği 1924 yılında mübadil yerleştirilen iskân mıntıkalarında bulunan etüv makineleri ve buğu sandıklarının adedi ve türü aşağıdaki tabloda verilmiştir: ${ }^{48}$

Tablo 1: İskân Mıntıkalarımdaki Etüv Makineleri ve Buğu Sandıkları

\begin{tabular}{|l|l|c|c|c|}
\hline $\begin{array}{l}\text { İskân } \\
\text { Mıntıkası }\end{array}$ & Vilayet & $\begin{array}{c}\text { Seyyar Etüv } \\
\text { Makinesi }\end{array}$ & $\begin{array}{c}\text { Sabit Etüv } \\
\text { Makinesi }\end{array}$ & $\begin{array}{c}\text { Buğu } \\
\text { Sandığ }\end{array}$ \\
\hline \multirow{4}{*}{$\begin{array}{l}\text { Samsun } \\
\text { Mintıkas1 }\end{array}$} & Sinop & 2 & & \\
\cline { 2 - 5 } & Samsun & 1 & 1 & \\
\cline { 2 - 5 } & Ordu & & 1 & 1 \\
\cline { 2 - 5 } & Giresun & & 1 & 1 \\
\cline { 2 - 5 } & Trabzon & \multicolumn{3}{|c}{} \\
\hline
\end{tabular}

45 Nuran Yıldırım, 14. Yüzyıldan Cumhuriyet'e Hastalıklar, Hastaneler, Kurumlar, Tarih Vakfi Yurt Yayınları, İstanbul, 2014, s. 438-439.

46 Neşet Ömer, a.g.e., s. 14.

47 Başustaoğlu, a.g.e., s. 273-274.

48 1925-1926 Türkiye Cumhuriyeti Devlet Salnamesi, Matbaa-i Amire, İstanbul, 1926, s. 274-275. 


\begin{tabular}{|c|c|c|c|c|}
\hline & Gümüşhane & & & 3 \\
\hline & Amasya & 1 & & 8 \\
\hline & Tokat & & & 10 \\
\hline & Çorum & 1 & & 6 \\
\hline \multirow{5}{*}{$\begin{array}{l}\text { Trakya } \\
\text { Mintıkası }\end{array}$} & Edirne & 1 & 1 & \\
\hline & Kırklareli & 1 & & 2 \\
\hline & Tekirdağ & 3 & & 4 \\
\hline & Gelibolu & & & \\
\hline & Çanakkale & 2 & 1 & \\
\hline $\begin{array}{l}\text { Balıkesir } \\
\text { Mıntıkası }\end{array}$ & Karesi & 2 & 2 & 7 \\
\hline \multirow{6}{*}{$\begin{array}{l}\text { İzmir } \\
\text { Mintıkası }\end{array}$} & İzmir & 4 & & 4 \\
\hline & Manisa & & & 3 \\
\hline & Aydın & & 1 & 1 \\
\hline & Menteşe & & 1 & \\
\hline & Afyon & & 1 & 6 \\
\hline & Denizli & 1 & & \\
\hline $\begin{array}{l}\text { Bursa } \\
\text { Mintıkas1 }\end{array}$ & Hüdavendigar & 5 & 1 & 3 \\
\hline \multirow{3}{*}{$\begin{array}{l}\text { İstanbul } \\
\text { Mintıkası }\end{array}$} & İstanbul & 27 & 23 & \\
\hline & Çatalca & 2 & 1 & \\
\hline & Zonguldak & 1 & & 2 \\
\hline \multirow{5}{*}{$\begin{array}{l}\text { İzmit } \\
\text { Mıntıkası }\end{array}$} & İzmit & 3 & & 10 \\
\hline & Bolu & 2 & & 4 \\
\hline & Bilecik & & & 4 \\
\hline & Eskişehir & 1 & 1 & \\
\hline & Kütahya & 3 & & 7 \\
\hline \multirow{3}{*}{$\begin{array}{l}\text { Antalya } \\
\text { Mintıkası }\end{array}$} & Antalya & 1 & & 9 \\
\hline & Isparta & 1 & 1 & 4 \\
\hline & Burdur & & & 4 \\
\hline \multirow{5}{*}{$\begin{array}{l}\text { Konya } \\
\text { Mintıkası }\end{array}$} & Konya & 3 & 2 & 2 \\
\hline & Niğde & & 1 & 12 \\
\hline & Kayseri & 4 & & 8 \\
\hline & Aksaray & & & 5 \\
\hline & Kırşehir & & & 2 \\
\hline \multirow{6}{*}{$\begin{array}{l}\text { Adana } \\
\text { Mintıkası }\end{array}$} & Adana & 1 & & 4 \\
\hline & Mersin & 2 & & 5 \\
\hline & Silifke & 1 & & 1 \\
\hline & Kozan & & & 1 \\
\hline & $\begin{array}{l}\text { Cebeli } \\
\text { Bereket }\end{array}$ & & & 5 \\
\hline & Gazi Antep & 2 & & 2 \\
\hline
\end{tabular}




\begin{tabular}{|l|l|l|l|l|}
\hline & Maraş & & 1 & 4 \\
\hline
\end{tabular}

Tahaffuzhanelerde muayeneleri yapılan ve eşyaları etüvden geçirilen mübadillerin temizlik ihtiyaçlarını karşılamak için Kızılay Genel Merkezi'nden imdad-1 sihhi heyetlerine gereği kadar temizlik malzemesi ve eşya gönderilmiş ve bu heyetler aracılığıyla mübadillere dağıtımı sağlanmıştır. Mübadele süresince 4220 kilo tuvalet sabunu ve 6000 kilo adi sabun mübadillere dağıtılmıştır. Ayrıca 899 adet entari, 1725 adet şalvar, 1631 adet şilte ve kıl minder, 1334 adet yastık, 399 adet yastık yüzü, 71 kilo basma, 149 adet eteklik, 404 adet hırka, 49.192 metre Amerikan bezi, 33.210 adet battaniye, 31.593 adet don, 2657 adet don fanila, 25.335 adet gömlek, 10.759 adet fanila, 10.756 adet çocuk çamaşırı, 51.813 çift çorap, 14.365 adet ceket, 18.449 adet pantolon, 10.605 adet kaput, 9216 adet yorgan, 8267 çift ayakkabı, 1100 çift çarık, 468 çift patik, 460 takım elbise, 3117 takım çocuk elbisesi, 1893 takım pijama, 5751 metre patiska, 6760 metre pazen, 5928 takım kadın elbise ve çamaşırı, 5765 adet mintan, 5436 adet yelek, 2561 adet fes, 2280 adet şilte kılıfi, 2213 adet çarşaf, 1978 adet peçete ve havlu Mübadele, İmar ve İskân Vekâleti ile Kızılay tarafından mübadillere dağıtılmıştır. ${ }^{49}$

1924 yılı Mart ayı başlarında Yunanistan'da üç münferit tifüs vakası görülmesi, ${ }^{50}$ mübadele işiyle meşgul olan mercileri daha dikkatli davranmaya sevk etmiştir. Örneğin, 1 Mart 1924 tarihinde Mübadele, İmar ve İskân Vekâleti'ne bir telgraf çeken Bursa Vali Vekili Kemal Bey, tifüs hastalığının görüldüğü Kavala'dan Akdeniz Vapuruyla Mudanya'ya getirilmekte olan mübadillerin önce Tuzla Tahaffuzhanesi'ne götürülerek sağlık kontrolleri ve temizlik işlemlerinin yapılmasını istemiş, vapur doğrudan Mudanya'ya gelse dahi Tuzla'ya gönderileceğini bildirmiştir. Mübadele İmar ve İskân Vekâleti Hıfzıssıhha Mütehassısı Muhittin Bey tarafindan 2 Mart 1924 tarihinde verilen cevapta mübadillerin bindirme iskelelerinde muayeneden geçirilerek temizlik işlemlerine tabi tutulduğu ve vapur yolculuğu süresince vapurlarda görevli doktorlar tarafından sağl1k kontrollerine devam edildiği belirtilmiştir. Ayrıca indirme iskelelerinde görev yapan imdad-1 sihhi heyetleri doktorları tarafindan da muayene edildikten sonra iskân mahallerine sevk edildikleri bildirilerek endişeye mahal verecek bir durumun olmadığı ifade edilmiştir. ${ }^{51}$ Yunanistan'da tifüs vakalarının görüldüğü bu günlerde mübadillerin tahaffuzhanelere uğramadan

49 Türkiye Hilal-i Ahmer Cemiyeti Merkez-i Umumisi Tarafından 1341 Senesi Hilal-i Ahmer Meclis-i Umumisine Takdim Edilen (1339-1340) İki Senelik Devreye Ait Rapor, s. 18-23.

50 THAM, III/31, 15 Mart 1924, s. 226-227.

51 BCA, 272/79-72-2-1. 
doğrudan iskân mahallerine sevklerinden duyulan rahatsızlığı ifade eden bir diğer isim ise Sihhiye ve Muavenet-i İçtimaiye Vekili Refik (Saydam) Bey olmuştur. 3/4 Mart 1924 tarihinde Mübadele, İmar ve İskân Vekâleti'ne gönderdiği bir yazıda Sulh Vapuru ile İzmit'e getirilen mübadillerin bitli olduğu ve İzmit'te mübadilleri temizleyecek etüv makinesi bulunmadığ 1 yönünde şikâyetler aldığını belirten Refik Bey, vapur doktorlarının bit tespit ettikleri mübadil kafilelerini tahaffuzhanelere götürmeleri için gerekli emirlerin verilmesini rica etmiştir. 5 Mart'ta Mübadele, İmar ve İskân Vekili namına cevap veren Hıfzıssıhha Mütehassısı Muhittin Bey, Bursa Vali Vekili'ne karşı olduğundan daha açık sözlü davranmış, Tuzla Tahaffuzhanesi'nde yeteri kadar misafirhane bulunmadığını ve mübadillerin temizlik işlemleri sırasında kar ve yağmura maruz kaldıklarını belirtmiştir. $\mathrm{Bu}$ olumsuzluklar yüzünden sağlam olan mübadillerin dahi hastalığa tutulduklarını ve vefatların daha da arttığını ifade etmiştir. Refik Bey'in 27/29 Mart tarihli cevabinda ise Tuzla Tahaffuzhanesi'nde 24 saatte 800 kişinin temizlik işlemlerinin tamamlanabildiği, daha önceden de bildirildiği gibi tahaffuzhanenin yukarı kısımlarındaki barakaların camlarının tamir ettirilip soba temin edildiği takdirde sorunun ortadan kalkacağ 1 belirtilmiştir. $^{52}$

Tahaffuzhanelerdeki yoğunluk nedeniyle her kafileyi tahaffuzhanelere yönlendiremeyen Mübadele, İmar ve İskân Vekâleti o günlerde mübadil nakledilecek bölgelerdeki önlemleri arttırma tedbirine başvurmuştur. 5 Mart 1924 tarihinde Antalya ile Adana İmar ve İskân Mıntıkaları Müdürlerine birer yazı gönderen Hıfzıssıhha Mütehassısı Muhittin Bey, Antalya ve Mersin'de etüv makinesi olup olmadığ seyyar mı yoksa sabit mi oldukları, gelecek mübadiller için bunlardan ne dereceye kadar yararlanılabileceği gibi sorular sormuş ve acilen cevap verilmesini istemiştir. ${ }^{53}$ Antalya İmar ve İskân Mıntıkası Müdürü Hüsnü Bey, 7 Mart 1924 tarihinde gönderdiği cevapta belediyeye ait bir etüv makinesi mevcut olduğunu ve şimdiye kadar gelen mübadillerin temizliklerinin bununla yapıldığını ayrıca bir seyyar etüv makinesine daha ihtiyaç duyulduğunu bildirmiştir. 10 Mart 1924 tarihinde verilen cevapta mevcut etüv makinesi yeterli gelmediği takdirde icab1 kadar buğu sandığ 1 yapılarak temizlik işlemlerinin bu surette yapılması emredilmiştir. ${ }^{54}$ Vekâletten gelen bu cevap üzerine 1924 yılı içinde Antalya'da dokuz buğu sandığı inşa edilmiştir. ${ }^{55}$ Adana İmar ve İskân Mıntıkası Müdürü Emin Bey

52 BCA, 272/79-72-2-7.

53 BCA, 272/79-72-2-3.

54 BCA, 272/79-72-2-8.

55 1925-1926 Türkiye Cumhuriyeti Devlet Salnamesi, s. 274. 
tarafindan 8 Mart 1924 tarihinde gönderilen cevapta ise Mersin'de biri Mersin İmdad-1 Sihhi Heyeti'ne diğeri ise Mersin Gureba Hastanesi'ne ait olmak üzere iki adet etüv makinesi bulunduğu ve bunlardan istifade edildiği bildirilmiştir. ${ }^{56}$ Mevcut etüv makinelerinin durumu hakkında 1924 y1lı Mart ayında bilgi istenen bir diğer mıntıka da Samsun İmar ve İskân Mıntıkası olmuştur. Samsun'daki etüv sıkıntısı Mıntıka Müdürü Mehmet Rıfat Bey'in vekâlete gönderdiği 24 Aralık 1923 tarihli bir yazı ile vekâletin bilgi istemesinden aylar önce bildirilmişti. Etüv makinesinin bulunduğu bina misafirhanelere uzak bir yerde olduğundan sahildeki misafirhanelere yakın metruk binalardan birine taşınması ve bu iş için Kızılay'dan para talep edilmesi istenmiş, Mübadele, İmar ve İskân Vekâleti, 30 Aralık'ta bu isteği Kızılay'a iletmişti. ${ }^{57}$ Ocak ayı başında etüv makinesinin misafirhanelere yakın bir binaya taşınması için Kızılay Genel Merkezi'nden Samsun İmdad-1 Sıhhi Heyeti'ne 100 lira gönderilmiş ancak bu para binanın tamirine yetmemiştir. Etüv makinesinin durumunun sorulması üzerine 15 Mart 1924 tarihinde vekâlete bir telgraf çeken Mıntıka Müdürü Mehmet Rıfat Bey, etüv makinesinin misafirhanelere yakın bir binaya taşınması için tekrar talepte bulunmuş, Ocak ayında başlanan tamir işleminin tamamlanabilmesi için 100 liraya daha ihtiyaç duyulduğunu ifade etmiştir. Hifzıssıhha Mütehassısı Muhittin Bey imzasıyla 18 Mart'ta gönderilen cevapta ise etüv makinesinin sahilde tamire muhtaç bir binaya taşınmak istenmesindeki maksadın anlaşılamamış olduğu bildirilmiştir. ${ }^{58}$ Samsun ile Ankara arasındaki bu yazışmalardan sonra etüv makinesi ile ilgili bir başka yazışmaya rastlanmamış, bu konuya nasıl bir çözüm getirildiği tespit edilememiştir.

Tifüse karşı alınan tedbirlerin arttırılmaya çalışıldığı Mart ayında Türkiye'deki ilk vaka haberi Tekirdağ'dan gelmiştir. Trakya İmar ve İskân Mintıkası Müdürü Ali Seyfi Bey, 13 Mart 1924 tarihinde Mübadele, İmar ve İskân Vekâleti'ne gönderdiği bir yazıda Tekirdağ'da iki sabit bir şüpheli olmak üzere üç tifüs vakası görüldüğünü vekâlete bildirmiştir. ${ }^{59}$ Hıfzıssıhha Mütehassıs1 Muhittin Bey tarafından 15 Mart 1924 tarihinde gönderilen cevabi yazıda yapılması istenenler dört maddede sıralanmıştır:

1- Tifüs vakalarının çıkış noktasının tespit edilerek bildirilmesi;

2- Gelmiş ve gelmekte olan mübadillerin muayenelerine ve bit mücadelesine önem verilmesi;

56 BCA, 272/79-72-2-3.

57 BCA, 272/11-16-70-22.

58 BCA, 272/11-17-71-10; BCA, 272/79-72-2-12.

59 BCA, 272/11-17-79-7. 
3- Merkezde tifüsle mücadele edecek bir sıhhi teşkilat oluşturulması ve Kızılay doktorlarından icabı kadarının köylere gönderilerek hastalığın takibinin yapılması;

4- Hastalığın yayılmasına ve mübadillere sirayet etmesine meydan verilmemesi. ${ }^{60}$

Trakya İmar ve İskân Mıntıkası Müdürü Ali Seyfi Bey’in, Mübadele, İmar ve İskân Vekâleti'ne 17 Mart'ta gönderdiği cevapta Tekirdağ'daki hükümet doktorunun tifüs vakaları konusunda gösterdiği çabanın sonuç verdiği, merkezdeki mübadiller için bit temizliğine önem verildiği ve buna devam edileceği vurgulanmıştır. Ayrıca köyleri dolaşmak suretiyle meskûn mübadillerin muayenelerini yapacak iki doktorun görevlendirilmesi için Tekirdağ İmdad-ı Sihhi Heyeti'ne yazıldığı ve meselenin takip edileceği ifade edilmiştir. Tekirdağ'daki durum hakkında detaylı bilgilere sahip olan Mübadele, İmar ve İskân Vekâleti, 23 Mart 1924 tarihinde Sihhiye ve Muavenet-i İçtimaiye Vekâleti'ni de durumdan haberdar etmiş, 26 Mart 1924 tarihinde verilen cevapta memleketin hemen hemen her bölgesinde tifüs vakaları görüldüğünün altı çizilerek alınan tedbirlerin devam ettirilmesi istenmiştir. ${ }^{61}$ Belediye doktoru Ziya Bey tarafından tespit edilen tifüs vakaları bölgenin yerel basınında da yer bulmuştur. Örneğin, Paşaili gazetesinin 23 Mart 1924 tarihli nüshasında Tekirdağ'da bir buçuk aydan beri tifüs hastalığının görüldüğü belirtilerek hala tifüslü iki hasta bulunduğu ve birinin hayati tehlikesinin devam ettiği duyurulmuş, mahalli tedbirlerin yetersizliğinden bahsedilerek hükümet göreve çağırılmıştır. ${ }^{62}$

Tifüs hastalığından şüphelenilen bir diğer bölge de İzmir İmar ve İskân Mıntıkası olmuştur. Mübadele, İmar ve İskân Vekili Celal (Bayar) Bey, İzmir mıntıkasını ziyareti sırasında Foça'da tifüse benzer bir hastalığa yakalanmış bir mübadil olduğunu görmüş ve Ankara'daki merkez teşkilat kadrosunu durumdan haberdar etmiştir. 19 Mart 1924 tarihinde İzmir İmar ve İskân Mıntıkası Müdürü Cemil Bey tarafından vekâlete gönderilen telgrafta Foça'ya yerleştirilen mübadillerin Kavala mübadilleri olduğu, Kavala civarındaki Yunan ordusunda tifüs hastalığı görüldüğünden bu bölgeden mübadil getirilen İzmir mıntıkasındaki önlemlerin daha da arttırıldığı bildirilmiştir. Hıfzıssıhha Mütehassısı Muhittin Bey'in 22 Mart'ta gönderdiği cevapta hastalığın tifüs hastalığı olup olmadığının tespit edilmesi ve kati bilgilerin gönderilmesi istenmiştir. Yapılan tahkikat neticesinde vakanın tifüs olmadığ 1 anlaşılmış ve 24 Mart'ta vekâlete bildirilmiştir. ${ }^{63}$

60 BCA, 272/14-76-29-2.

61 BCA, 272/79-72-2-15.

62 Paşaili, 23 Mart 1340.

63 BCA, 272/79-72-2-13. 
Tifüs hastalığına karşı uyarılan mıntıkalardan biri de Samsun İmar ve İskân Mıntıkası olmuştur. Sıhhiye ve Muavenet-i İçtimaiye Vekili Refik Bey, 23 Mart 1924 tarihinde Samsun Sihhiye Müdürlüğü’ne gönderdiği bir yazıda Selanik'teki Rum mübadiller arasında iki tifüs vakası görüldügünü bildirmiştir. Selanik'ten gelecek mübadillerin s1k1 bir muayeneden geçirilmelerini, ateşi yüksek olanların müşahede altında tutulmalarını, mübadillerin temizliğine dikkat edilmesini ve şüpheli bir vaka görülmesi halinde derhal bilgi verilmesini istemiştir. Samsun Sihhiye Müdürlüğü, 24 Mart'ta Samsun İmdad-1 Sihhi Heyeti'ni de durumdan haberdar etmiştir. ${ }^{64}$ Kizilay Genel Sekreteri Doktor Hikmet Bey'in 26 Mart 1924 tarihinde Mübadele, İmar ve İskân Vekâleti'ne gönderdiği bir yazı ile durum daha da netlik kazanmış, Kozana, Kayalar'ın Çalcılar ve Soroviç'in Eleviç karyelerinde tifüs hastalığı görüldüğü haberinin alındığı bildirilmiştir. Bu bölgelerdeki mübadiller Samsun'a getirileceğinden Samsun'da bulunan tüm yetkililer tekrar uyarılmıştır. ${ }^{65} 6$ Nisan 1924 tarihinde Samsun'a yapılan uyarılara benzer bir uyarı da Selanik'te bulunan görevlilere yapılmış, mübadillerin sık1 bir sağlık kontrolünden geçirildikten sonra vapurlara bindirilmeleri ve vapur doktorlarının durumdan haberdar edilmeleri istenmiştir. Mübadele, İmar ve İskân Vekili Celal Bey, Atina'da bulunan Muhtelit Mübadele Komisyonu Türk Heyeti Reisi Tevfik Rüştü (Aras) Bey’i de durumdan haberdar ederek durumu bizzat takip etmesini rica etmiştir. ${ }^{66}$

Alınan tüm tedbirlere rağmen 26 Nisan 1924 tarihinde Samsun'da bir tifüs vakası görülmüştür. Bu ilk vakayı 30 Nisan tarihli yeni bir vaka takip etmiş, 1 Mayıs'a gelindiğinde Samsun İmdad-ı Sihhi Heyeti eczacısı, iki hastabakıcı kadın, bir misafirhane hademesi ve ahali arasından beş kişinin daha tifüse yakalandığı tespit edilmiştir. ${ }^{67}$ Samsun'daki tifüs vakalarının artması ve sağlık çalışanlarına da bulaşması üzerine sağlık çalışanı sayısının arttırılması yönünde bir tedbire başvurulmuştur. $\mathrm{Bu}$ çerçevede Samsun İmdad-1 Sihhi Heyeti kadrosuna iki doktor, iki hemşire ve iki hastabakıcı daha dâhil edilmiştir. ${ }^{68}$ Alınan bir diğer tedbir ise bir süreliğine mübadil sevkiyatına ara vermek olmuştur. Mıntıka Müdürü Mehmet Rıfat Bey, 28 Nisan'da Mübadele, İmar ve İskân Vekâleti'ne bir telgraf çekerek Samsun'da bulunan mübadillerin çoğunun daimi iskân bölgelerine sevk edilemediklerini ve Sungurlu'ya iskân edilen mübadillerde de tifüs vakaları görüldüğünü bildirmiştir. Bu duruma istinaden 26 Nisan'da Kavala'dan

64 TKDA, Kutu No: 639, Belge No: 1.24.

65 BCA, 272/79-72-2-17; BCA, 272/79-72-2-23; TKDA, Kutu No: 639, Belge No: 1.22.

66 BCA, 272/79-72-2-23.

67 TKDA, Kutu No: 639, Belge No: 1.20; TKDA, Kutu No: 639, Belge No: 1.18; TKDA, Kutu No: 639, Belge No: 1.17.

68 THAM, III/33, 15 May1s 1924, s. 291. 
hareket eden Sulh vapurundan sonra Samsun'a 20 gün mübadil sevkiyatı yapılmamasını istemiştir. Bu telgraf üzerine Atina ve Kavala'daki yetkililer durumdan haberdar edilmiş, denizyolu ya da demiryoluyla Samsun'a gönderilecek mübadil kafilelerinin sevkiyatlarının en az 10 gün ertelenmesi ricasında bulunulmuştur. ${ }^{69}$

Yunanistan'dan Samsun'a sevk edilen mübadillerin vapur yolculukları dokuz günü buluyor, son derece elverişsiz şartlarda yapılan bu yolculuk birçok mübadilin sağlık durumlarında bozulmalara yol açıyordu. ${ }^{70}$ Vapurlar Samsun'a gelmeden önce tahaffuzhaneye ya da başka bir limana uğramışlarsa hasta olan mübadiller oralarda indirilerek tedavi altına alınıyordu. Örneğin, İnönü vapuruyla Selanik'ten Samsun'a nakil edilen mübadillerden birinin yolculuk sırasında tifüse yakalandığ İstanbul'da indirilerek hastaneye yatırılmıştı. ${ }^{71}$ Uzun ve elverişsiz bir yolculuğun ardından Samsun'a varan mübadiller, Samsun'daki misafirhanelere alınıyor, misafirlik süreleri bazen üç haftaya kadar çıkabiliyordu. Misafirhanelerin yetersizliğinden başını sokacak bir çatı dahi bulamayan mübadiller, sokaklar, bahçeler, kabristanlar, pazar yerleri gibi açık mekânlarda konaklamak zorunda kalıyorlardı. Samsun'daki mübadil yığılmasının 10.000'in üzerine çıktığı dönemler dahi oluyor, misafirhanelerde misafir edilemeyen mübadillerin sağlik kontrollerini ve temizlik kontrollerini yapmak son derece güç bir hal alıyordu. ${ }^{72}$

Samsun'daki mübadil yığılmasının hat safhaya ulaştığı bu günlerde görülen tifüs vakalarındaki artış devam etmiştir. 3 Mayıs'ta tespit edilen yeni bir vakayı, 13 Mayıs'ta Kayalar mübadilleri arasında görülen beş yeni vaka izlemiş, 14 Mayıs'ta Kayalar mübadilleri arasında bir, 15 Mayıs'ta yine Kayalar mübadilleri arasında dört yeni vakaya daha rastlanmıştır ${ }^{73}$. Tifüs vakalarındaki artış Samsun'un yerel basınında da yer bulmuş, Haber gazetesinin 15 Mayıs 1924 tarihli nüshasında Samsun Sihhiye ve Muavenet-i İçtimaiye Müdüriyeti'nin tifüs hastalığı hakkında bilgi ve tavsiyelerini içeren bir yazı yayımlanmıştır. Bahsi geçen yazının ilgili bölümleri aşağıda aynen verilmiş̧ir:

69 BCA, 272/14-76-31-6.

70 Çapa, a.g.e., s. 175.

71 İkdam, 19 Haziran 1924.

72 Türkiye Büyük Millet Meclisi Zabıt Ceridesi, Devre II, İçtima Senesi II, Cilt 9, TBMM Matbaası, Ankara, 1975, s. 105; Nedim İpek, Mübadele ve Samsun, Türk Tarih Kurumu Yayınları, Ankara, 2000, s. 55; Arı, Büyük Mübadele, s. 97.

73 TKDA, Kutu No: 639, Belge No: 1.16; TKDA, Kutu No: 639, Belge No: 1.15; TKDA, Kutu No: 639, Belge No: 1.12; TKDA, Kutu No: 639, Belge No: 1.11 . 
"Son günlerde şehrimizde [Samsun] lekeli humma ve kara humma hastalıkları zuhur etmiştir:

Lekeli humma: Bitlerle insandan insana intikal eder. Buna yakalanmamak için bitlenmemek icap eder. Bunun için saç ve sakalı kısa kesmek vücutta başka mahallerde fazla kıl bırakmamak ve daima elbisede çamaşırda bit aramak, sık çamaşır değiştirmek ve sık yıkanmak, bitli insanlardan uzak bulunmak, kalabalık mahallere sokulmamak velhasıl taharet-i nezakate dikkat ve itina etmek ve bit almamak lazım. .... Her iki hastalık da etibba tarafından teşhis edilebileceği cihetle vaktiyle haberdar olunarak lazım gelen tedabir ittihaz edilmek ve bu suretle hem hastanın hayatı kurtarılmak hem de etraf ve temasta bulunanların vikaye edilebilmeleri için bu gibi zamanlarda her ateşli hastanın behemehâl tabibe müracaat etmesi ve herkesin de duyduğu hastaları sihhiyeye, belediyeye ihbar etmeleri menfaat-i umumiye ve emraz-1 sâriye nizamnamesi iktizasındandır. Lekeli humma için maelteessüf aşı yoktur."’74

16 Mayıs'a gelindiğinde yine Kayalar mübadilleri arasında iki yeni vaka görülmüştür. 16 Mayıs'tan 19 Mayıs'a kadar geçen üç gün yeni vaka görülmemiş, 19 Mayıs'ta Kayalar mübadillerinden bir kadının tifüse yakalandığı tespit edilmiştir. 22 Mayıs'a kadar geçen üç gün yine yeni vaka görülmemiş, 22 Mayıs'ta ise Kayalar mübadillerinden iki mübadilin daha tifüse yakalandığ 1 anlaşılmıştır. Tifüse yakalanan hastalar Samsun İmdad-1 Sihhi Heyeti Hastanesi'nde tecrit altına alınmışlardır. 28 ve 29 Mayıs tarihlerinde tifüs kaynaklı ilk vefatlar gerçekleşmiş, 28 Mayıs'ta bir, 29 Mayıs'ta dört kişi hayatını kaybetmiştir. ${ }^{75}$

Nisan ve Mayıs aylarında Anadolu'nun diğer şehirlerinde de tifüs vakaları görülmeye başlamıştır. Nisan ayı içinde İzmit yoluyla Konya'ya sevk edilen Kozana mübadillerinden iki kişi tifüs hastalığına yakalanmıştır. ${ }^{76}$ 27 Mayıs 1924 tarihinde Samsun Sihhiye ve Muaveneti İçtimaiye Müdüriyeti'ne bir yazı gönderen Sıhhiye ve Muaveneti İçtimaiye Vekili Refik Bey, sayı vermemekle birlikte İzmit yoluyla Konya, Aksaray, Niğde ve Kayseri'ye sevk edilen, Mersin yoluyla Ulukışla ve Niğde'ye sevk edilen Serfice mübadillerinde ve Samsun yoluyla Tokat, Çorum ve Sivas'a sevk edilen mübadiller arasında birçok tifüs vakası görüldüğünü bildirmiştir. Gelen mübadillerden bitli ve ateşli olanların kafilelerden ayrılması ve bu

74 Haber, 15 May1s 1340.

75 TKDA, Kutu No: 639, Belge No: 1.10; TKDA, Kutu No: 639, Belge No: 1.9; TKDA, Kutu No: 639, Belge No: 1.8; TKDA, Kutu No: 639, Belge No: 1.6; TKDA, Kutu No: 639, Belge No: 1.5 .

76 TKDA, Kutu No: 88, Belge No: 23. 
kişilerle temasta bulunanların da tecrit altında tutulmaları istenmiştir. ${ }^{77}$ Sıhhiye ve Muavenet-i İçtimaiye Vekâleti'nin, Hudut ve Sahil Sihhiye Müdüriyeti'nden aldığı bilgilere göre ise 24 Mayıs'ta Giresun vapuruyla Selanik'ten Kavak Tahaffuzhanesi'ne getirilen mübadillerde iki tifüs vakasına rastlanmış, bu hastalardan biri vefat etmiştir. 3/4 Haziran 1924 tarihinde Mübadele, İmar ve İskân Vekâleti ile Kızllay da durumdan haberdar edilmiş, iskân mıntıkalarındaki görevlilerin uyarılması ve gerekli tedbirlerin alınması istenmiştir ${ }^{78}$. Samsun başta olmak üzere Anadolu'nun birçok şehrinde görülen tifüs vakalarındaki artış dönemin ulusal basınında da yer bulmuştur ${ }^{79}$. Tifüs vakalarının ulusal basında yer bulması mübadeleyi yürütmekle doğrudan vazifeli olmayan mülki amirleri de daha dikkatli davranmaya sevk etmiştir. Örneğin, 29 Mayıs 1924 tarihinde Bakırköy Kızılay Şubesi’ne başvuran Bakırköy Kaymakamı mübadillerin çoğunun bitli olduğunu ve temizlik için kullanılacak sabun bulunamadığını belirtmiş, mübadillere dağıtılmak üzere 2 çuval sabun gönderilmesi talebinde bulunmuştur. Talebin Kızılay Genel Merkezi'ne iletilmesi üzerine Bakırköy'de iskân edilen mübadillere dağıtılmak üzere bir sandık sabun gönderilmiştir. ${ }^{80}$

Mübadele, İmar ve İskân Vekâleti'nin 1924 yılı Mayıs ayı faaliyetlerinin yayınlandığı bir haberden edindiğimiz bilgilere göre Mayıs ayında Konya, Samsun, Tokat ve Çorum vilayetlerinde bulunan mübadiller arasında 156 tifüs vakası görülmüştür. Bunlardan 138'i sağlığına kavuşurken 18 'i vefat etmiştir. ${ }^{81}$ Haziran ayına girildiğinde tifüs vakalarında azalma gözlemlenmiş, 26 Haziran'da Samsun'da görülen 2 tifüs vakası dışında başka bir vaka görülmemiştir. ${ }^{82}$ Temmuz ayındaki tek vaka ise Kayalar'ın Cuma karyesinden gelen bir mübadilde görülmüş, hasta Samsun İmdad-1 Sihhi Heyeti hastanesinde tedavi altına alınmıştır. ${ }^{83}$ Ağustos ayında Tokat'ın Niksar ve Erbaa kazalarında iskân edilen Drama mübadilleri arasında tifüs vakaları görülmesi üzerine Reşadiye kazası Sıhiyye Memuru Dr. Nuri Turgut Efendi Niksar ve Erbaa'ya giderek 15 gün kadar bu bölgelerdeki mübadillerin durumunu yakından incelemiştir. ${ }^{84}$ Eylül ayının ilk günlerinde Çorum'dan yeni bir tifüs vakası haberi gelmiştir. Samsun İmar ve İskân Mıntıkası Müdürlüğü 3 Eylül'de Mübadele, İmar ve İskân Vekâleti'ni, 4

77 TKDA, Kutu No: 639, Belge No: 1.1.

78 TKDA, Kutu No: 88, Belge No: 195; TKDA, Kutu No: 21, Belge No: 173.

79 İkdam, 18 Mayıs 1924.

80 TKDA, Kutu No: 1353, Belge No: 86.

81 Hâkimiyet-i Milliye, 19 Haziran 1924.

82 TKDA, Kutu No: 639, Belge No: 26.

83 TKDA, Kutu No: 639, Belge No: 51.

84 TKDA, Kutu No: 639, Belge No: 79. 
Eylül'de ise Sihhiye ve Muavenet-i İçtimaiye Vekâleti'ni durumdan haberdar etmiş, gerekli sıhhi tedbirlerin alınması için Çorum Sıhhiye ve Muavenet-i İçtimaiye Müdüriyeti'ne emir buyrulmasını rica etmiştir ${ }^{85} 22$ Eylül'de Sivas Sihhiye Müşaviri tarafından Mübadele, İmar ve İskân Vekâleti'ne gönderilen bir telgrafta Hafik'te iskân edilen mübadiller arasında da tifüs vakaları görüldügü haberi verilmiştir. Aynı gün gönderilen bir başka telgrafta mübadillerin iskân edildikleri mahallerde kalmayarak dolaştıkları, Tokat ve Samsun'a kadar gidip gelmeleri yüzünden oralardan hastalık kaptıkları belirtilmiş, eşyaların etüvden geçirildiği ve mübadillerin hamamlarda yıkandıkları bildirilmiştir. Vekâletin 23 Eylül tarihli yazısında vakaların çıkış noktasının tespit edilip tedbirlerin arttırılması, 25 Eylül tarihli yazısında ise seyyar doktor tayin edilerek mübadillerin muayenelerinin yapılması istenmiştir. ${ }^{86}$ Aynı günlerde Milas'ta da tifüs vakaları görülmesi üzerine İzmir İmar ve İskân Mıntıka Müdürlügünden vakalar hakkında bilgi istenmiştir. İzmir İmar ve İskân Mıntıkası Müdürü Cemil Bey'in 28 Eylül'de gönderdiği cevapta Milas'taki tifüs vakalarının yerli halk arasında görüldüğü ve mübadillere sirayet etmediği bildirilmiştir. ${ }^{87}$

Eylül ayı sonlarında Selanik'te tekrar tifüs vakaları görülmüss, Mübadele, İmar ve İskân Vekâleti Hıfzıssıhha Mütehassısı Muhittin Bey, 1 Ekim'de gönderdiği bir yazıyla bütün İmar ve İskân Mıntıka Müdüriyetlerini durumdan haberdar ederek gerekli tedbirlerin alınmasını ve sağlık kontrollerine azami derecede önem verilmesini istemiş̧ir ${ }^{88}$ Yaptığımız arşiv taramalarında bu tarihten sonra kayıtlara geçen bir tifüs vakasına rastlanmamıştır. Mübadele süresince görülen tifüs vakalarının kayıtlarının düzenli bir şekilde tutulduğunu söylemek de güçtür. Birçok belgede sadece tifüs vakalarının görüldüğ̈̈ bölgeler belirtilmiş, vaka sayıları ve tifüs kaynaklı vefat sayıları verilmemiştir. 1924 yılında görülen tifüs vakaları hakkında net sayılara ulaşabildiğimiz tek kaynak 1925-1926 Türkiye Cumhuriyeti Devlet Salnamesi olmuştur. Ancak bu kaynakta da sadece tifüs vakalarının toplam sayısı ile toplam vefat sayısı verilmiş, görüldükleri şehirler hakkında bilgi verilmemiştir. 1925-1926 Türkiye Cumhuriyeti Devlet Salnamesi’ne göre, 1924 yılında 919 tifüs vakası görülmüş, 110 kişi tifüs hastalığından hayatını kaybetmiştir. 1924 yılında Türkiye genelinde 101.871 kişinin vefat ettiği göz önünde tutulursa tifüs kaynaklı vefatların

\footnotetext{
BCA, 272/79-72-3-11.

86 BCA, 272/79-72-3-23; BCA, 272/79-72-3-28.

87 BCA, 272/79-72-3-22.

88 BCA, 272/79-72-4-2.
} 
toplam vefat sayısı içindeki oranının ne derece düşük - \% 0,10 - olduğu görülecektir. ${ }^{89}$

\section{Sonuç}

Birinci Dünya Savaşı ve Milli Mücadele yıllarında salgın halini alarak Anadolu'nun hemen hemen her bölgesinde görülen tifüs hastalığ birçok kişinin hayatını kaybetmesine neden olmuştur. Milli Mücadelenin son bulmasından 14 ay sonra başlayan ve bir yılı aşkın bir süre devam eden mübadele sürecinde de Anadolu'nun bazı bölgelerinde tifüs hastalığına rastlanmıştır. Ancak bu süreçte görülen tifüs hastalığı Birinci Dünya Savaşı yıllarında olduğu gibi salgın halini almamış, tifüs kaynaklı kayıplar, Birinci Dünya Savaşı yıllarında yaşanan kayıpların çok gerisinde kalmıştır. Mübadeleyi tatbik etmekle görevli kurumların bu başarıdaki rolü büyüktür. Mübadele işlerini organize etmek için hususi bir vekâlet kurularak geniş bir kadro oluşturulmuştur. Ancak yeni kurulan bir vekâletin aksaksız bir şekilde çalışması da beklenemezdi. Özellikle sağlık konularında yaşanabilecek s1kıntılar öngörülerek daha Mübadele, İmar ve İskân Vekâleti'nin kurulmasından evvel Kızılay ile anlaşılmış, mübadelenin sağlık işleri Kızılay ile koordineli bir şekilde yürütülerek karşılaşılabilecek sorunlar asgariye indirilmiştir. Trablusgarp Savaşı, Balkan Savaşları, Birinci Dünya Savaşı ve Kurtuluş Savaşı'nda cepheden cepheye koşan Kızılay, bu savaşlar nedeniyle imkânlarının çoğunu tüketmiş olmasına rağmen mübadele sürecinde de elinden gelen her türlü fedakârlığ yapmıştır. Sağlık işleri konusunda zaman zaman Kızılay'ın da yetersiz kaldığı yerler ve bölgeler olmuş, bu gibi durumlarda Sihhiye ve Muavenet-i İçtimaiye Vekâleti’nin desteği alınarak karşılaşılan güçlüklerin üstesinden gelinmiştir.

Mübadele sürecindeki tifüs vakalarının büyük çoğunluğu Samsun mıntıkası dâhilindeki Orta Karadeniz ve İç Anadolu şehirlerinde görülmüş̧ür. $\mathrm{Bu}$ durum Samsun mıntıkasının Yunanistan'dan mübadil nakliyatı yapılan en uzak mıntıkalardan biri olmasından kaynaklanmış, mübadillerin çoğu sağlık durumları bozulmuş bir vaziyette Samsun'a varmışlardır. Ancak bu mıntıkadaki şehirlerde görülen tifüs vakalarının fazlalığını sadece uzun ve elverişsiz yolculukla açıklamak da güçtür. Tifüs vakalarının görüldüğü şehirlerin çoğunda hastalıkla mücadelede en etkili gereç olan etüv makinelerinin noksanlığı göze çarpmaktadır. Misafirhanelerin yetersizliğinin de etkisiyle mübadillerin çoğu kontrol altında tutulamamış, kişisel temizlikleri sağlanamamıştır. Bu eksikler sonucunda Samsun civarındaki tifüs vakaları diğer bölgelerdeki vakalara nazaran çok daha fazla olmuştur. Tekirdağ ve Milas gibi bazı iskân

89 1925-1926 Türkiye Cumhuriyeti Devlet Salnamesi, s. 290. 
mıntıkalarında yerel halk arasında tifüs vakalarına rastlandığ mübadillere sirayet etmemiş olması iskân konusunda Samsun'a kıyasla daha az sıkıntılarla karşılaşılmış olunmasıyla açıklanabilir. Mübadele yıllarında tifüs hastalığına karşı koruyucu bir aşı ve tedavi amaçlı kullanılan etkili bir ilacın henüz bulunamamış olması da göz önünde tutulduğunda tifüse karşı son derece başarılı bir mücadelede verilmiş, hastalığın salgın halini alarak daha geniş alanlara yayılmasının önüne geçilmiştir.

\section{KAYNAKÇA}

\section{Arşivler}

Devlet Arşivleri Başsanlığı Cumhuriyet Arşivi

BCA, 272/12-40-40-3.

BCA, 30/10-123-873-3.

BCA, 272/79-72-3-33.

BCA, 272/79-72-2-1.

BCA, 272/79-72-2-3.

BCA, 272/79-72-2-8.

BCA, 272/79-72-2-12.

BCA, 272/11-16-70-22.

BCA, 272/11-17-71-10.

BCA, 272/11-17-79-7.

BCA, 272/14-76-29-2.

BCA, 272/79-72-2-15.

BCA, 272/79-72-2-13.

BCA, 272/79-72-2-7.

BCA, 272/79-72-2-17.

BCA, 272/79-72-2-23.

BCA, 272/14-76-31-6.

BCA, 272/79-72-3-11.

BCA, 272/79-72-3-23.

BCA, 272/79-72-3-28. 
BCA, 272/79-72-3-22.

BCA, 272/79-72-4-2.

Türkiye Kızılay Derneği Arşivi

TKDA, Kutu No: 1296, Belge No: 151.

TKDA, Kutu No: 88, Belge No: 106.

TKDA, Kutu No: 639, Belge No: 1.24.

TKDA, Kutu No: 639, Belge No: 1.22.

TKDA, Kutu No: 639, Belge No: 1.20.

TKDA, Kutu No: 639, Belge No: 1.18.

TKDA, Kutu No: 639, Belge No: 1.17.

TKDA, Kutu No: 639, Belge No: 1.16.

TKDA, Kutu No: 639, Belge No: 1.15.

TKDA, Kutu No: 639, Belge No: 1.12.

TKDA, Kutu No: 639, Belge No: 1.11.

TKDA, Kutu No: 639, Belge No: 1.10.

TKDA, Kutu No: 639, Belge No: 1.9.

TKDA, Kutu No: 639, Belge No: 1.8.

TKDA, Kutu No: 639, Belge No: 1.6.

TKDA, Kutu No: 639, Belge No: 1.5.

TKDA, Kutu No: 88, Belge No: 23.

TKDA, Kutu No: 639, Belge No: 1.1.

TKDA, Kutu No: 88, Belge No: 195.

TKDA, Kutu No: 21, Belge No: 173.

TKDA, Kutu No: 1353, Belge No: 86.

TKDA, Kutu No: 639, Belge No: 26.

TKDA, Kutu No: 639, Belge No: 51.

TKDA, Kutu No: 639, Belge No: 79.

Resmi Yayınlar 
1925-1926 Türkiye Cumhuriyeti Devlet Salnamesi, Matbaa-i Amire, İstanbul, 1926.

İskân Tarihçesi, Hamit Matbaası, İstanbul, 1932.

Türkiye Büyük Millet Meclisi Zabıt Ceridesi, Devre II, İçtima Senesi II, Cilt 9, TBMM Matbaası, Ankara, 1975.

Türkiye Hilal-i Ahmer Cemiyeti Merkez-i Umumisi Tarafindan 1341 Senesi Hilal-i Ahmer Meclis-i Umumisine Takdim Edilen (1339-1340) İki Senelik Devreye Ait Rapor, Hilal Matbaası, İstanbul, 1341.

Kitaplar

Aghatabay, Cahide Zengin, Mübadelenin Mazlum Misafirleri Mübadele ve Kamuoyu 1923-1930, Bengi Kitap Yayın, İstanbul, 2009.

Aksu, Lutfi, Lekeli Humma (Tifüs), Ulusal Matbaa, Ankara, 1943.

Arı, Kemal, Büyük Mübadele, Türkiye'ye Zorunlu Göç (1923-1925), Tarih Vakfı Yurt Yayınları, İstanbul, 2000.

Türk Ticaret-i Bahriyesi ve Mübadele Gemileri, Deniz Ticaret Odası İzmir Şubesi Yayınları, İzmir, 2009.

Başustaoğlu, Ahmet, Bir Nefes Sıhhat, Tevfik Sağlam'ın Yaşamı, Türkiye İş Bankası Yayınları, İstanbul, 2016.

Çakmak, Zafer, İzmir ve Çevresinde Yunan İşgali ve Rum Mezalimi (19191922), Yeditepe Yayınevi. İstanbul, 2007.

Çapa, Mesut, Kızllay [Hilal-i Ahmer] Cemiyeti (1914-1925), Türkiye Kızılay Derneği Yayınları, Ankara, 2010.

Çelebi, Ercan, Mübadele, İmar ve İskân Vekâleti (Kuruluşu, Teşkilât Yapısı ve Faaliyetleri), Hiperyayın, İstanbul, 2019.

Çınar, Semih, Mübadelede Tekirdăg, Hilal-i Ahmer (Kızılay) Cemiyeti'nin Mübadele Yıllarında Tekirdağ Faaliyetleri (1923-1924), Hiperyayın, İstanbul, 2021.

Emgili, Fahriye, Yunanistan'dan Mersin'e, Köklerinden Koparılmış Hayatlar, Bilge Kültür Sanat, İstanbul, 2011.

Gökaçtı, Mehmet Ali, Nüfus Mübadelesi, Kayıp Bir Kuşağın Hikâyesi, İletişim Yayınları, İstanbul, 2010.

İpek, Nedim, Mübadele ve Samsun, Türk Tarih Kurumu Yayınları, Ankara, 2000.

Lekeli Humma, Sihhat ve İçtimaî Muavenet Vekâleti Neşriyatı, Ankara, 1943.

Lozan Barış Konferansı Tutanaklar Belgeler, Çev. Seha L. Meray, Takım I, Cilt 1, Kitap 2, Ankara Üniversitesi Basımevi, Ankara, 1969. 
McCarthy, Justin, Ölüm ve Sürgün, Çev. Fatma Sarıkaya, Türk Tarih Kurumu Yayınları, Ankara, 2014.

Neşet Ömer, Bitler, Bitlerin Ahval-i Hayatiye ve Vesait-i İtlafiyesi Lekeli Tifo ve Humma-yı Racianın Bitler ile Sirayeti, Kudüs, 1332.

Noyan, Abdülkadir, Son Harplerde Salgın Hastalıklarla Savaşlarım, Ankara Tıp Fakültesi Yayınları, Ankara, 2019.

Özalp, Kazım, Milli Mücadele 1919-1922, Cilt I, Türk Tarih Kurumu Yayınları, Ankara, 1998.

Özkan, Salih, Mübadele ve Niğde'ye Yapılan İskan, Köymen Yayınevi, Konya, 2010.

Sağlık Hizmetlerinde 50 Yıl, Sağlık ve Sosyal Yardım Bakanlı̆̆ı Yayınları, Ankara, 1973.

Soysal, İsmail, Türkiye'nin Siyasal Andlaşmaları I. Cilt (1920-1945), Türk Tarih Kurumu Basımevi, Ankara, 2000.

Yıldırım, Nuran, 14. Yüzyıldan Cumhuriyet'e Hastalıklar, Hastaneler, Kurumlar, Tarih Vakfi Yurt Yayınları, İstanbul, 2014.

\section{Makaleler}

Arı, Kemal, "Cumhuriyetin İlk Yıllarında Yaşanan Göç Olayları ve Sağlık Hizmetleri”, Atatürk Dönemi Sağlık Tarihi Kongresi (1920-1938), İzmir, 2009, ss. 105-113.

“Mübadele Göçmenlerini Türkiye’ye Taşıma Sorunu ve İzmir Göçmenleri (1923-1924)", Çağdaş Türkiye Tarihi Araştırmaları Dergisi, Cilt I, Say1 1, (1991), ss. 13-46.

Çanlı, Mehmet, "Yunanistan'daki Türklerin Anadolu'ya Nakledilmesi II", Tarih ve Toplum, Cilt 22, Say1 130, (Ekim 1994), ss. 243-251.

Çelebi, Ercan, "Yunanistan'dan Gelen Mübadillere Sunulan Sağlık Hizmetleri: Hilâl-i Ahmer İmdat Sihhî Heyetleri ve Faaliyetleri”, Yeni Türkiye, Rumeli Balkanlar Özel Sayısı IV, Y1l 21, Sayı 69, (Mart-Haziran 2015), ss. 42264230.

Erdal, İbrahim, "Mübadil Göçmenlerin Taşınması Meselesi ve Türk Vapurcuları İle Yapılan Nakil Sözleşmesi”, Atatürk Yolu, Cilt: 8, Sayı: 31-32, (Mayıs-Kasım 2003), ss. 313-328.

Özer, Sevilay, "Birinci Dünya Savaşı'nda Osmanlı Devletinde Tifüs (Lekeli Humma) Salgını", Belleten, Cilt: LXXX, Sayı: 287, (Nisan 2016), ss. 219-260. 
Tekir, Süleyman, "Sarıkamış Harekâtı Sonrası Türk Ordusunda Görülen Salgın Hastalıklar ve Yaşanan Kayıplar", Kafkas Üniversitesi Sosyal Bilimler Enstitüsü Dergisi, Ek Sayı 1, (Sonbahar 2016), ss. 267-287.

\section{Süreli Yayınlar}

Haber

Hâkimiyet-i Milliye

Hilal-i Ahmer

İkdam

Paşaili

Türkiye Hilal-i Ahmer Mecmuası 